\title{
Bank Funding Costs for International Banks
}




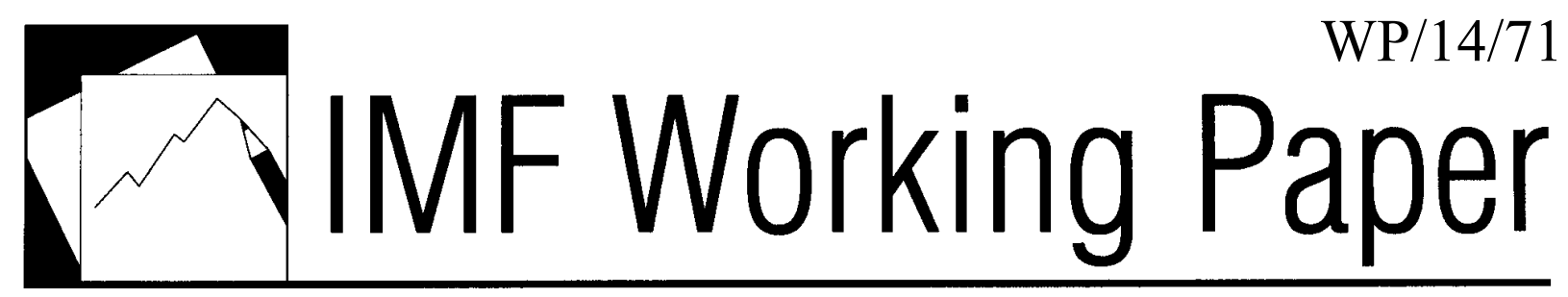

Bank Funding Costs for International Banks

Rita Babihuga and Marco Spaltro 


\title{
IMF Working Paper
}

\author{
European Department
}

\section{Bank Funding Costs for International Banks}

\section{Prepared by Rita Babihuga and Marco Spaltro ${ }^{1}$}

\author{
Authorized for distribution by Krishna Srinivasan
}

April 2014

\begin{abstract}
This Working Paper should not be reported as representing the views of the IMF.
The views expressed in this Working Paper are those of the author(s) and do not necessarily represent those of the IMF or IMF policy. Working Papers describe research in progress by the author(s) and are published to elicit comments and to further debate.
\end{abstract}

\begin{abstract}
This paper investigates the determinants of bank funding costs for a sample of internationally active banks from 2001-12. We find that changes in banks' unsecured funding costs are associated with bank-specific characteristics such as an institution's credit worthiness and the return on its market value, and importantly, on the level and quality of capital. Similarly, market factors such as the level of investor risk appetite, as well as shocks to financial markets - notably the US subprime crisis and the Euro Area sovereign debt crisis - have also been key drivers of the sharp rise in bank funding costs. We also find evidence that large systemically important institutions have enjoyed a funding advantage, and that this advantage has risen since the onset of the two crises. With the exception of Euro Area periphery banks, by end-2012 the rise in funding costs had generally been reversed for most major banks as a result of improvments in bank asset quality as well as steps taken to increase resilience, notably higher capitalization. Our results suggest increased capital buffers may potentially support bank lending to the real economy by reducing bank funding costs.
\end{abstract}

JEL Classification Numbers: G01, G21, G15.

Keywords: bank funding, bank lending, financial crises, capital, deposit, wholesale funding.

Authors’ E-Mail Address: rbabihuga@imf.org and marco.spaltro@morganstanley.com

\footnotetext{
${ }^{1}$ When this paper was written, Rita Babihuga was on secondment at the Bank of England. We would like to thank Krishna Srinivasan and Ali Abbas from the IMF, as well as Martin Brooke, Chris Peacock, Nicole Anderson, Lewis Webber, Gabriele Zinna and Ron Smith from the Bank of England for their helpful comments and suggestions.
} 


\section{INTRODUCTION}

1. One important legacy of the global financial and Euro Area (EA) crises is their impact on the funding models of internationally active banks. In the period preceding the crisis, many of the largest global banks had experienced difficulty attracting core deposits. Increasingly, they supplemented stable retail deposits with readily available funding raised in wholesale markets, which allowed them to fund the increase in demand for credit during the credit boom ${ }^{2}{ }^{3}$. This growing reliance on short term wholesale finance to fund long term assets created major vulnerabilities for banks in the form of currency and maturity mismatches, and increased liquidity risk. As the global financial crisis unfolded, global banks faced destabilization in funding markets, with market funding becoming either unavailable or prohibitively expensive. Overall, banks that had relied more on customer deposit funding fared better during the crisis, and there is evidence that their market value exceeded banks that had funded predominantly through wholesale markets (Beltratti and Stultz, 2011).

2. Bank funding markets experienced significant paralysis from 2007-12 as the sub-prime crisis gave way to the EA crisis. The start of the global financial crisis in August 2007 was characterized by major banks experiencing liquidity shortages worldwide and a period of increased turmoil in interbank funding markets, in which interest rates on interbank lending rose sharply. Interbank lending slowed to a halt, wholesale funding markets froze shut and interest rates on unsecured term loans between banks rose significantly and remained unusually volatile for an extended period of time. Funding conditions remained tight as investors continued to shun bank debt, and new issuance fell to historic lows (Figure 1).

3. As a result, banks' reliance on market funding has fallen, reflected in narrowing customer funding gaps and the sharp decline in bank debt issuance (Figures 1-2). By 2007, the growth in customer loans had exceeded growth in customer deposits by far, particularly for Nordic, Euro Area (EA) and UK banks. They bridged this funding gap with short term and collateralized term funding from wholesale markets. At their peak in March 2007, banks in the major European countries and the US issued some US\$415 billion in secured and unsecured debt, compared to some US\$8bn just over a decade earlier. Since 2007, capital market issuance has fallen sharply for the majority of global banks, as have customer funding gaps. Banks responded to the scarcity and increased cost of wholesale funding during and after the global financial crisis by either: (i) shifting towards more customer deposit funding where possible ${ }^{4}$, (ii) relying on official financing sources; and/or (iii) reducing non-core assets.

\footnotetext{
${ }^{2}$ The growth of wholesale funding markets in the decades prior to the crisis had itself reflected a convergence of factors, including the increasing institutionalization of savings with corporations and institutional investors in need of products with deposit-like features in which to place their cash balances (see Pozsar et. al, (2012)).

${ }^{3}$ Wholesale funds included short term unsecured funding raised through the interbank market, commercial paper and certificate of deposit instruments; short term secured funding in the form of repos and money market funding; as well as longer term secured and unsecured debt

${ }^{4}$ There was evidence of increased deposit competition in several countries post -2007, for example in Spain, Portugal and the UK. As government liquidity facilities expired in Spain, banks stepped up their efforts to attract
} 
Figure 1. Global Banks' Debt Issuance(a)

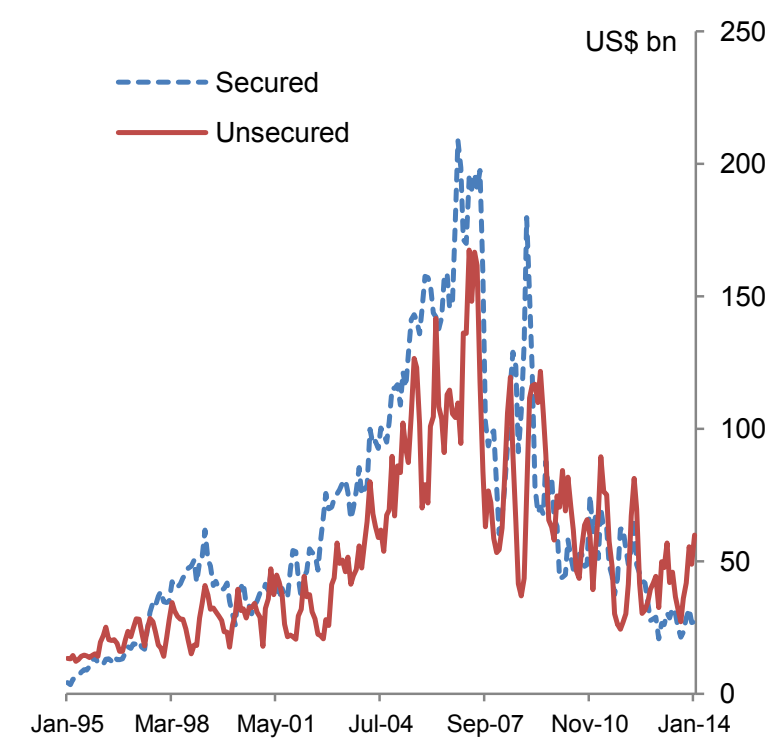

Source: Dealogic and authors' calculations

(a) Issuance of term bank senior secured and unsecured debt. Includes major international banks in the Euro Area, the US, UK and Nordic countries.
Figure 2. Customer Funding Gaps ${ }^{(a)(b)}$

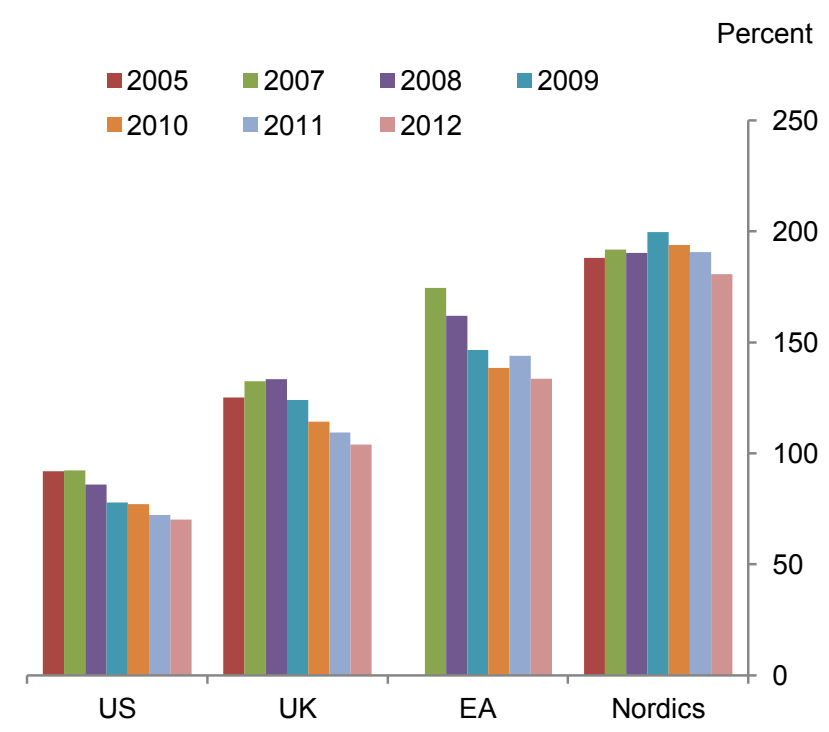

Source: FDIC, ECB and SnL Financial.

(a) Defined as customer loan to deposits ratio

Nordics includes Sweden, Denmark and Norway

4. This paper focuses on the factors underlying the cost of international banks' funding. As discussed earlier, bank's funding costs rose sharply from the onset of the global financial crisis. And yet, notwithstanding the generalized deterioration in wholesale funding markets, there was heterogeneity between banking systems and indeed within them, as funding costs varied across individual banks. We explore the factors explaining these differences, including why funding costs have come down faster for some global banks than others. In particular, we investigate the relative importance of bank-specific balance sheet variables, country-specific macro-financial factors and global financial market factors in explaining changes in banks' funding costs in the period leading up to, and during the global financial and EA sovereign debt crises. Our approach allows us to disentangle the effects of steps taken by banks to increase resilience-including through higher capitalization - on bank funding costs, as well as assess the impact of the financial crisis and associated turbulence in funding markets on long run funding costs.

5. The analysis focuses on a bank's marginal cost of funding. Depending on their business model and the structure of their balance sheet, banks raise funding from a range of different sources: customer deposits, from households and businesses, and unsecured and secured wholesale markets, from other lenders and institutional investors. Yet the overall cost of funding

retail deposits and began to engage in aggressive commercial policies from 2009-10, which prompted regulators to issue new rules that explicitly linked the risk assumed by an institution with its deposit insurance contributionsthis effectively limited the rates that banks could pay for deposits. 
achieved by a bank is quite complex and difficult to get at-it is specific to the structure of liabilities and will also ultimately depend on the interest rate characteristics of these liabilities ${ }^{5}$. As such, we focus on a bank's cost of raising an additional unit of funding - the marginal cost of funding. In the run-up to the crisis, banks had increasingly used wholesale unsecured funding markets as their marginal source of funding given they could raise substantial amounts of funds, relatively cheaply and at short notice in these markets (Button, Pezzini and Rossiter (2010)). This reflected the willingness of institutional investors to provide significant amounts of wholesale funding at short notice, unlike retail deposits for example which might be slower to mobilize ${ }^{6}$. Therefore our analysis excludes funding costs deriving from secured funding (e.g. covered bonds or repo) and deposits ${ }^{7}$.

6. Throughout the paper we assume that changes in banks' marginal unsecured wholesale funding costs can be inferred from five-year CDS premia. Credit default swaps (CDS) for banks, which measure the cost of insuring against default on unsecured bonds, provide a useful indicator for the cost of senior debt, as they are likely to capture the marginal unsecured cost of funds. Drawing on the methodology described in Button et al. (2010) we estimate a bank's marginal funding cost as the sum of its five-year CDS premia plus three-month Libor, reflecting the cost of raising fixed rate senior unsecured bonds and entering into an interest rate swap where the bank receives a series of fixed-rate cash flows and pays a series of floating-rate cash flows.

We find evidence that short run changes in bank unsecured funding costs are associated with: (i) bank-specific characteristics such as an institution's credit worthiness, and importantly, changes in the level and quality of capital; (ii) country level factors such as domestic economic conditions and changes in short term interest rates; and (iii) global risk factors such as implied market volatility, shocks to financial markets - notably the recent global financial crisis and EA sovereign risks - and the global growth outlook. We also find evidence that larger, systemically important banks enjoy a funding advantage, and this advantage has risen since the onset of the crisis. Overall, banks' funding costs in the long run appear to have risen over the sample period, mainly driven by the deterioration in banks' asset quality, the decline in domestic economic

\footnotetext{
${ }^{5}$ Also, banks often use derivative contracts to adjust the interest rate risk of their liability portfolio, the terms of which are likely to cause the overall portfolio cost to differ from that calculated simply by looking at the original fund raisings.

${ }^{6}$ Whether banks filled their customer funding gap with long-term or short-term (e.g., interbank loans) wholesale funding is unlikely to affect the marginal cost of funding prior to the financial crisis, as the cost of both types of funding was close to three-month Libor.

${ }^{7}$ These may also be less directly comparable across jurisdictions. For example, deposit rates may be subject to nonmarket forces in some jurisdictions - e.g., the deposit cap in the US and recent deposit rate caps in Spain.
} 
conditions, as well as the impact of successive financial crises - the global financial crisis and the EA sovereign debt crisis.

7. From a policy perspective our results counter the idea that higher capital requirements might lead to reduced lending to the real economy by increasing bank funding costs. Miles' (2011) analysis of optimal bank capital finds that higher bank equity financing raises overall funding costs only modestly, and concludes that the long-run impact of large increases in bank capital on the borrowing costs of customers is likely to be small. Admati, DeMarzo, Hellwig and Pfleiderer (2013) advance a similar argument, calling for higher levels of bank equity financing. Our findings suggest that increased capital buffers can indeed lead to a decline in a bank's funding costs in the long run. If the increase in capital buffers is due to higher quality Tier 1 capital, there is a short run reduction in funding costs as well. As such, regulatory efforts to strengthen banks' capital buffers may not necessarily raise banks' cost of capital and therefore lead to a reduction in lending to the real economy. While efforts to undertake balance sheet repair may reduce bank lending in the short run, we find that in the long run a higher capital level leads to lower bank funding costs, therefore potentially supporting bank lending growth.

8. The rest of the paper is organized as follows. Section II reviews the growing body of literature on bank funding. Section III presents an overview of the empirical model used to explain the evolution of bank funding costs. Section IV presents the data. Section V discusses the results of the empirical estimation, and Section VI concludes.

\section{REVIEW OF THE LITERATURE}

9. The funding structures of internationally active banks - both pre- and post-crisis - have been well documented. In particular, the ECB's 2009 report on EU bank' funding structures and policies illustrates the pre-crisis balance sheet growth of EA banks, funded by ever shortening maturities of money market funding, securitization and debt issuance, which exposed banks to both maturity and currency mismatches. The Committee on the Global Financial System (CGFS) has made several contributions to the literature on international banks' funding models. Using international banking statistics from the BIS, they illustrate the increased globalization of banks' funding operations in the period preceding the crisis. They also conclude that banks operating a more wholesale-oriented, cross-border based and centralized (liquidity management) funding model were disproportionately affected by funding problems during the global financial crisis in part due to intra-group funding contagion. The IMF's October 2013 GFSR attributes banks' choice of funding structure to bank-specific factors as well as macro financial and market variables.

10. Global bank funding models and the crisis-driven dislocation of wholesale funding markets have also been the focus of a number of recent empirical studies. One particular strand of the literature looks at why some banks performed better during the recent financial crisis. 
These studies find evidence that banks with a greater reliance on non-deposit funding faced the greatest funding difficulties and retrenched lending to the real economy the most. By contrast, deposit-funded banks continued to lend during the crisis compared to their peers, showed better overall performance and were less risky (Ivashina and Scarfstein (2010); Dermirguc-Kunt and Huizinga (2010); Raddatz (2010); Cornett, McNutt, Strahan and Tehranian (2011); Beltratti and Stulz (2012); Dagher and Kazimov (2012); Vazquez and Frederico (2012); IMF (2013)).

11. A number of studies focus on European banks' funding models given their disproportionately greater reliance on non-deposit funding sources compared to international peers. Successive financial market crises have had a damaging — but not irreversible - impact on EA banks' funding models, underscored by the large-scale, sustained intervention of the European Central Bank in providing bank funding (Le Lesle (2012), McKinsey (2013)). As a result bank funding costs have increasingly diverged across the EA, as periphery banks have experienced deposit flight and a higher spread on bank debt. In addition, secured debt financing has become more prevalent, and rising debt retention by EA banks has occurred alongside greater reliance on ECB liquidity (van Rixtel and Gasperini (2013)). Le Lesle (IMF, 2012) proposes a number of actions to repair European banks' funding models, including increased capital and liquidity requirements.

12. A separate strand of the literature investigates the "too-big-to-fail" funding cost subsidy - i.e., the extent of funding cost differences between banks that are perceived as being likely to be bailed-out if they were to fail and other banks (see for example, Araten and Turner (2012), Anginer, Acharya and Warburton (2013), Ueda and di Mauro (2011), Li, Qu and Shiseng (2011), Demirguc_Kunt and Huizinga (2011), and Baker and McArthur (2009)). These studies focus on the "total cost of funding", including the various sources of bank funding such as deposits and term bank debt. In general, they all find some evidence that globally systemically important banks (G-SIBs) have lower total funding costs, and attribute this advantage to their "too-big-to-fail" status.

13. The majority of empirical studies on CDS have tended to focus on sovereign and corporate CDS, but there are a few empirical studies of bank CDS (see Annex I Table 4). The majority of these studies precede the recent financial crisis, focus on explaining high frequency changes in CDS prices i.e., daily and weekly changes, and tend to use market based proxies to control for individual bank characteristics, given that the latter are only available on a quarterly frequency. In the pre-crisis literature on bank CDS, Chiaramonte and Casu (2007), is the only study to control for banks' balance sheet determinants but their analysis precedes the global financial crisis, covering a period of low volatility in CDS premia and does not control for nonbank specific characteristics. 
14. More recently, several studies of bank CDS have emerged which cover a period including the financial crisis. Eichengreen, Mody, Nedeljkovic and Sarno (2009) use principal components analysis to identify common factors in the movement of banks' CDS premia. They find evidence of a common factor in the evolution of banks' CDS premia - in other words, the fortunes of international banks rose and fell together even in normal times along with short-term global economic prospects, explaining why problems in a small corner of the US mortgage market were able to explode into a global financial crisis. Ballester Miquel, Lukac and González-Urteaga (2013) investigate the relationship between bank CDS premia for major European and US banks and banking fragility from 2004-12, and in particular the extent to which there exist common factors in these spreads. They find evidence of a change in the correlation between bank CDS premia, and in particular increased co-movement after the onset of the crisis.

15. Our contribution to the literature is two-fold: first we use bank CDS premia to explain the factors determining bank funding costs over a period of time that includes both the global financial and the EA sovereign debt crises; secondly, we investigate the importance of changes in bank capital for bank funding costs, and as such, the extent to which recent efforts by banks to increase balance sheet resilience may have had an impact on their funding costs.

\section{EMPIRICAL MODEL}

16. We model changes in bank funding costs as a function of changes and levels of balance sheet and macro financial variables, in the context of a panel Error Correction Model. This methodology allows us to disentangle long- and short-run effects of bank-specific and macro variables on funding costs and to estimate the long-run equilibrium of funding costs for major international banks.

17. We start by estimating the following dynamic linear regression model:

$$
\begin{aligned}
& \Delta F C_{i, t}=\alpha_{0}+\alpha_{1} F C_{i, t-1}+\beta_{0} \boldsymbol{K}_{i, t-2}+\gamma_{0} \boldsymbol{M}_{t-1}+\beta_{1} \Delta \boldsymbol{K}_{i, t-1}+\gamma_{1} \Delta \boldsymbol{M}_{t}+\delta_{1} \Delta \mathbf{Z}_{\mathrm{t}}+\varepsilon_{i, t}, \\
& \quad \alpha_{0}=\bar{\alpha}+\alpha_{c} C 1_{t}+\alpha_{d} C 2_{t}
\end{aligned}
$$

where $F C_{i, t}$ refers to bank $i$ 's marginal cost of funding (the sum of three-month Libor plus the

five-year CDS premia) at time $t, \mathbf{K}_{\mathrm{t}-2}$ is a vector of capital variables at time $t-2$ (total capital ratio and capital quality), and $\mathbf{M}_{\mathrm{t}-1}$ a vector of macro variables at time $t-1$ (real GDP growth, short 
term interest rate, yield curve slope) ${ }^{8}$ These variables generate both short and long-run effects on funding costs and therefore they are included both in levels and changes. ${ }^{9}$

18. $C l_{\mathrm{t}}$ is a financial crisis dummy taking value 1 from Q3 2007, which allows for a change in the relationship between funding costs and bank specific variables following the disruption of wholesale funding markets and the start of the global financial crisis in August 2007. $C 2_{\mathrm{t}}$ is a second financial crisis dummy that takes value 1 from Q2 2011, and allows for a change in the relationship between funding costs and bank specific variables following the market disruption from Q2 2011, triggered by market concerns about a potential break-up of the EA. Similarly, the constant is allowed to change during the crisis period, and when $\mathrm{C} 2$ takes the value of 1 , the effect of the second crisis dummy adds up to the first and the overall impact of both crisis episodes is cumulative.

19. Finally, $\mathbf{Z}_{\mathrm{t}}=\left[\mathbf{B}_{\mathrm{t}-1}, \mathbf{F}_{\mathrm{t}}\right]$ stacks a vector of bank-specific variables at time t-1 $\left(\mathbf{B}_{\mathrm{t}-1}\right)$ (provision ratio and equity returns) and macro-financial variables at time $t\left(\mathbf{F}_{t}\right)$ (market implied volatility and an index of notional weighted CDS premia for periphery European countries). The $\mathbf{Z}_{\mathrm{t}}$ variables have only short-run effects and therefore are included only in changes.

20. We find that the model is stable and therefore has the following error correction representation ${ }^{10}$ :

$$
\begin{gathered}
\Delta F C_{i, t}=\mu\left(F C_{i, t-1}^{*}-F C_{i, t-1}\right)+\beta_{1} \Delta \boldsymbol{K}_{i, t-1}+\gamma_{1} \Delta \boldsymbol{M}_{t}+\delta_{1} \Delta \mathbf{Z}_{\mathrm{t}}+u_{t,} \\
F C_{i, t}^{*}=-\left(\bar{\alpha}+\alpha_{c} C 1_{t}+\alpha_{d} C 2_{t}\right) / \alpha_{1}-\boldsymbol{K}_{i, t-1}-\gamma_{0} / \alpha_{1} \boldsymbol{M}_{t},
\end{gathered}
$$

whereby it takes $-1 / \mu$ quarters for funding costs to go back to the long-run value, $F C_{t}^{*}$, where $\beta_{1} \Delta \boldsymbol{K}_{i, t-1}+\gamma_{1} \Delta \boldsymbol{M}_{t}+\delta_{1} \Delta \mathbf{Z}_{\mathrm{t}}$ denotes the short-run dynamics.

\section{DATA}

21. The analysis is based on a comprehensive dataset which combines individual bank credit default swaps, balance sheet data on bank characteristics, data on country specific macroeconomic and financial factors, as well as global financial indicators, for a sample of 52 banks in 14 advanced economies from 2001-12. We use quarterly (instead of daily) CDS premia data given we are interested in investigating the impact of bank balance sheet variables, including bank capital on bank funding costs. These balance sheet variables are only available on a quarterly basis. Our primary data sources are Bloomberg and Datastream.

\footnotetext{
${ }^{8}$ We use lagged bank balance sheet variables to avoid any simultaneity bias.

${ }^{9}$ We have tested for the existence of long run relationships empirically by estimating an unrestricted model and excluded the levels for those variables that do not affect the CDS long-run equilibrium.

${ }^{10}$ The model is stable and has a long run relationship if $-1<\alpha_{1}<0$.
} 
22. We identify a core sample of the largest global banks, comprising 25 major international banks from four regions: US, UK, EA and Nordic countries ${ }^{11}$. The two criteria used for assessing the sample of core banks are: (i) the bank is systemically important within its economy at end-2012; and (ii) based on the availability of data on CDS premia over the period 2001-12 on a quarterly frequency ${ }^{12}$. 19 of the 25 banks in our core sample also meet the Financial Stability Board's classification as global systemically important banks at end-2012. We estimate the main equation (3) on this sample of 25 banks.

23. For the second specification, we test whether there is any evidence of a funding cost advantage for banks classified as systemically important banks. For this exercise we augment our dataset with an additional 30 banks, mainly reflecting the availability of data on CDS premia. The additions are European banks, a few US banks, as well as some Australian and Japanese banks.

24. Figure 3 shows banks' CDS premia from 2003-2013 across major banking systems. Not surprisingly there is some co-movement, with generalized increases during periods of global financial market stress. However, the size of the increase in premia has tended to vary by bank and across regions. For example, US banks experienced the sharpest rise in premia compared to any other banking system following the Lehman collapse in Q3 2008, diverging significantly from other major banking systems. In contrast, bank CDS premia rose in tandem for US, UK and EA banks during the EA crisis. And, despite moving quite closely over the most of the sample period, UK and EA bank CDS premia appear to have diverged around 2012, with UK bank spreads falling faster than EA bank spreads. Annex I Table 3 reports summary statistics on CDS premia for the individual banks in our sample. Average spreads over the period vary significantly across banks (from a low of 3.4 bps for Rabobank to a high of 2911 bps for Ally Financial).

25. Overall, there are some similarities in the evolution of bank CDS premia over the sample period. The period from 2001 to early-2007 was characterized by relative calm, with little volatility in CDS premia across all banks. Since then, key crisis events beginning in mid-2007 with the US sub-prime mortgage crisis, have preceded sharp widespread rises in bank CDS. The collapse of Lehman brothers in September 2008 marked a second escalation point with US banks' CDS in particular rising to unprecedented levels amid increased market fears about counterparty creditworthiness. Goldman Sachs, Citigroup and Morgan Stanley were most affected-Morgan Stanley's CDS peaked at 1240bp. On the other hand, the impact of the

\footnotetext{
${ }^{11}$ This includes Denmark, Sweden and Norway.

${ }^{12} \mathrm{We}$ opt for a quarterly frequency (contrary to other studies of CDS which use a daily or weekly frequency (see Annex I Table 4) in order to allow us to control for banks' balance sheet variables, which are only available on a quarterly basis.
} 
Lehman collapse on European, UK and Japanese banks' CDS was relatively more muted, with the increase in bank CDS significantly less than in the US. This episode points to common factors underlying the generalized rise in CDS, but also individual bank-specific and possibly market-specific factors explaining why some banks' CDS premia rose more than others.

26. The second major generalized rise in bank CDS premia began on April 23, 2010, with the Greek government's announcement that it had requested a bailout from the troika ${ }^{13}$ which effectively marked the beginning of the European sovereign debt crisis. EA, UK and US bank CDS rose several basis points as a result, but remained contained. However, Portugal's bailout in April 2011 sparked a widespread even sharper increase in bank CDS on the realization that the EA crisis was far from contained and there was a possibility of greater contagion to other peripheral European countries.

Figure 3. Bank CDS Premia ${ }^{(1)(2)}$

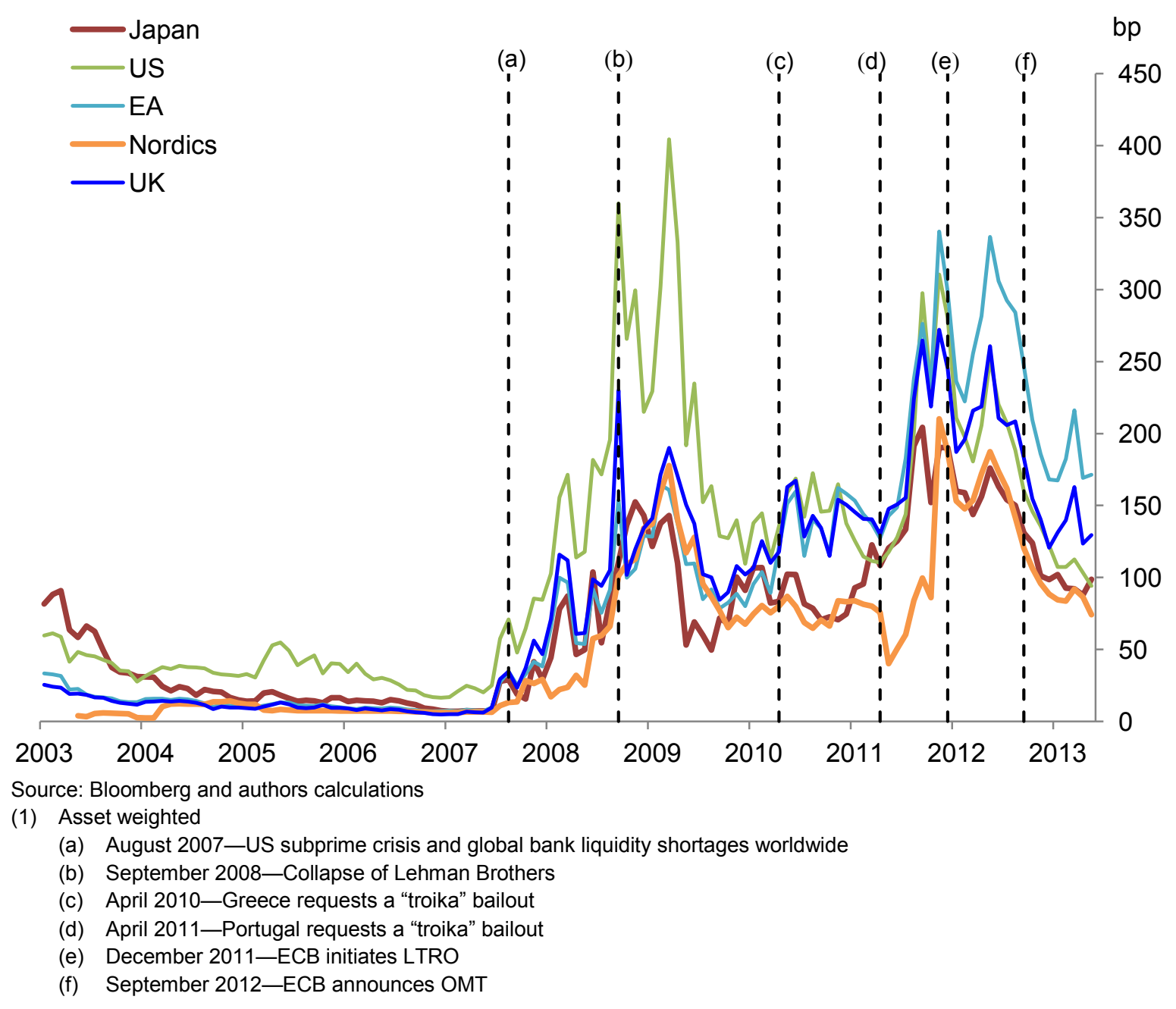

${ }^{13}$ The European Central Bank, the European Union and the International Monetary Fund. 
27. This phase of the global crisis saw European bank CDS premia in particular rising to their highest levels. US and UK banks' premia also rose to levels comparable to those of European banks, but did not resurge to the highs seen after the Lehman collapse. They did however remain elevated during 2011-12, and comparable at times to some European banks, suggesting some spill-over from the EA sovereign crisis. Among European banks, CDS premia rose to their highest levels among French and Italian banks, while increases among Nordic and German banks were relatively modest. European Central Bank (ECB) actions, in particular the second bank liquidity support program, the Long Term Refinancing Operation (LTRO) in December 2011 and the OMT in September 2012 preceded sharp falls in bank CDS premia.

28. Since September 2012, bank CDS premia have declined steadily across all regions. In September 2012, the ECB announced it would begin open-ended government bond purchases through its Outright Monetary Transactions (OMT) program as a backstop for EA countries, to prevent the spread of financial contagion. Following the subsequent steady decline, as of May 2013 bank CDS premia had settled at levels higher than their pre-crisis peaks with EA and UK banks experiencing a temporary rise in the context of market turbulence resulting from the crisis in Cyprus. While decidedly lower, bank CDS premia for US, Nordic and Japanese banks were all roughly more than 50 bps higher than they were at end-2006.

29. Figure 4 shows scatter plots of changes in bank funding costs plotted against a selected set of our control variables. We use changes in banks' provisioning and non-performing loans to proxy the ill-health of a bank's balance sheet, and a set of capital variables to proxy resiliencei.e., the ratio of total capital to total assets and tier 1 capital to proxy capital quality. The plots suggest a positive long run relationship between funding costs and banks' balance sheet health, and a negative long run relationship with both total capital and higher quality Tier 1 capital. According to the Modigliani-Miller theorem more equity financing should not necessarily lead to an increase in a bank's average cost of funds - although it may raise the ratio of expensive equity to cheaper debt, the higher average cost should be offset by lower required rates of return on both equity and debt ${ }^{14}$.

30. The vector of macro-financial variables includes actual domestic economic growth and expected global economic growth, reflecting the sizable domestic operations as well as taking account of the global nature of the operations of the banks in our sample. We have also included equity volatility and global market illiquidity indicators to control for the effects of broader market conditions on bank CDS. We also include the short term policy interest rate to reflect the monetary policy stance and the effect of short term interest rates on bank funding. We also include the slope of the nominal yield curve $(10 \mathrm{yr}-3 \mathrm{~m})$ to control for the impact of changes in

\footnotetext{
${ }^{14}$ This so-called "Modigliani-Miller (MM) offset" has been the subject of several empirical studies. Miles (2011) finds evidence of MM offsets in the case of UK banks, as does Kashyap et. al (2010) for US banks.
} 
term spread on a bank's funding costs. While increases in rates are expected to lead to increases in costs along the full maturity structure of a bank's funding (suggesting a positive relationship), the overall impact may be mitigated by a range of factors including an individual bank's maturity structure of funding as well as the impact of higher rates on the asset side of its balance sheet $^{15}$. There is a separate - macro channel - through which the yield curve spread could affect banks' credit risk and CDS, which suggests a positive relationship ${ }^{16}$.

31. We control for EA sovereign risk using an index constructed on the basis of the sovereign CDS premia of periphery European countries (Greece, Italy, Ireland, Portugal and Spain), weighted by notional amounts. We also include two crisis dummy variables: (i) crisis dummy one captures the onset of the sub-prime crisis in Q3 2007; and (ii) crisis dummy two captures a second period of extreme financial market stress and a second break in CDS premia, beginning in Q2 2011 triggered by concerns about a possible EA break-up.

\footnotetext{
${ }^{15}$ An increase in the yield curve spread should have a positive effect on a bank's net interest margin, improving profitability and reducing credit risk, suggesting a negative relationship between the yield curve spread and bank CDS.

${ }^{16}$ While a steepening yield curve slope is a leading indicator of a future economic recovery, in real time it is an indicator of weak economic conditions, implying a positive relationship between term spread and credit risk.
} 
Figure 4. Long Run Relationship between Funding Costs and Selected Control Variables

Bank Balance Sheet Health

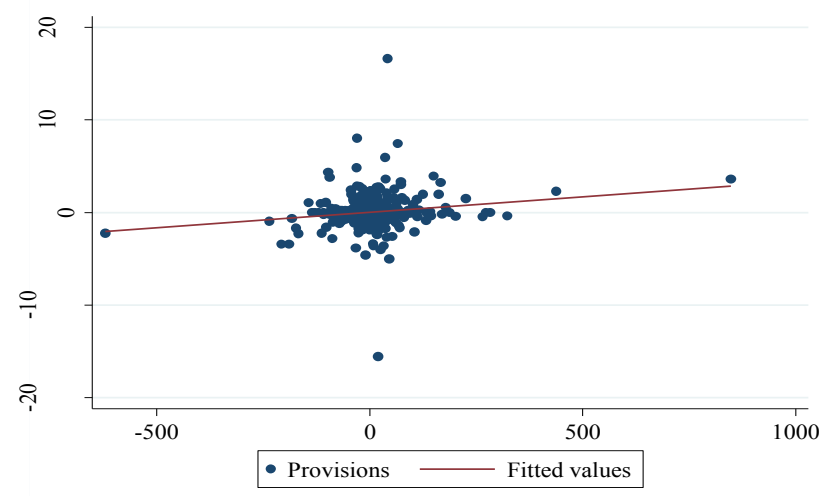

Tier 1 Capital

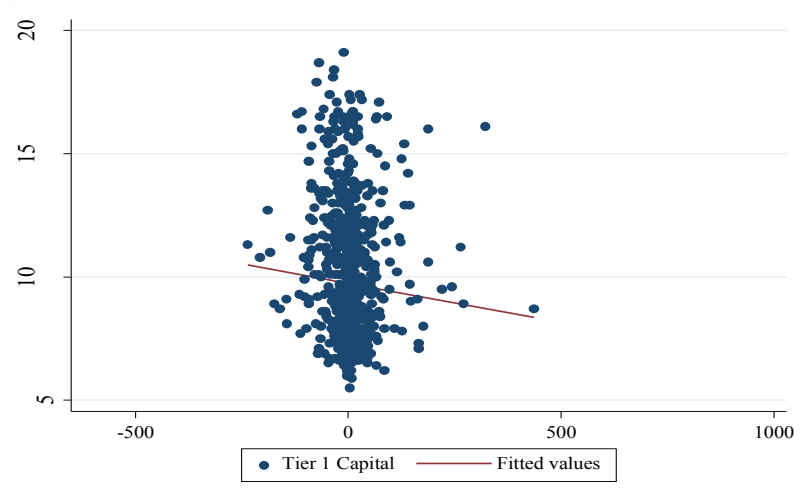

Financial Market Volatility

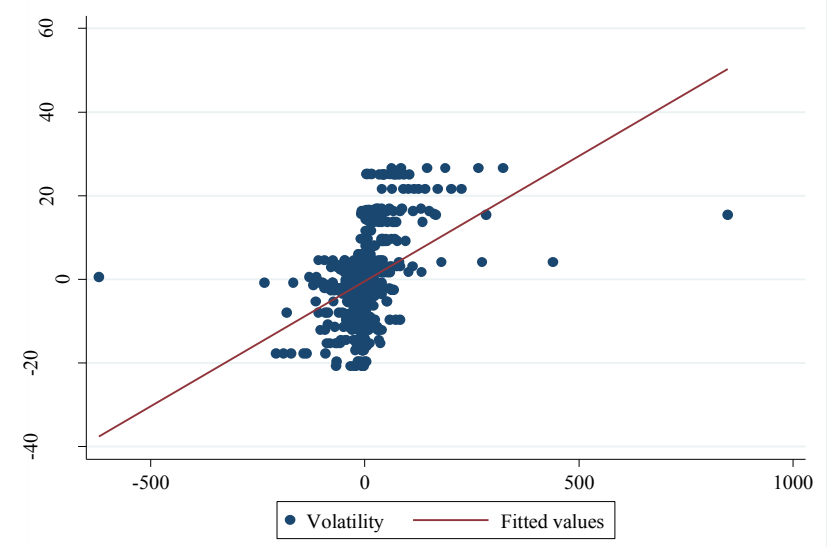

Total Capital

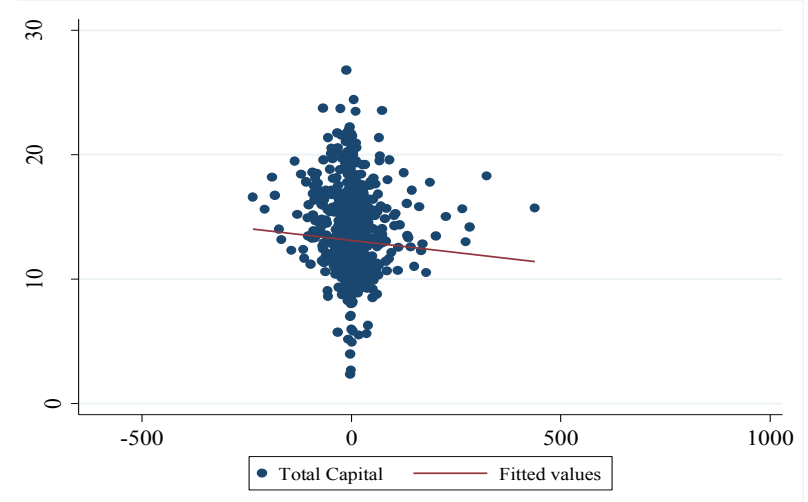

Real GDP Growth

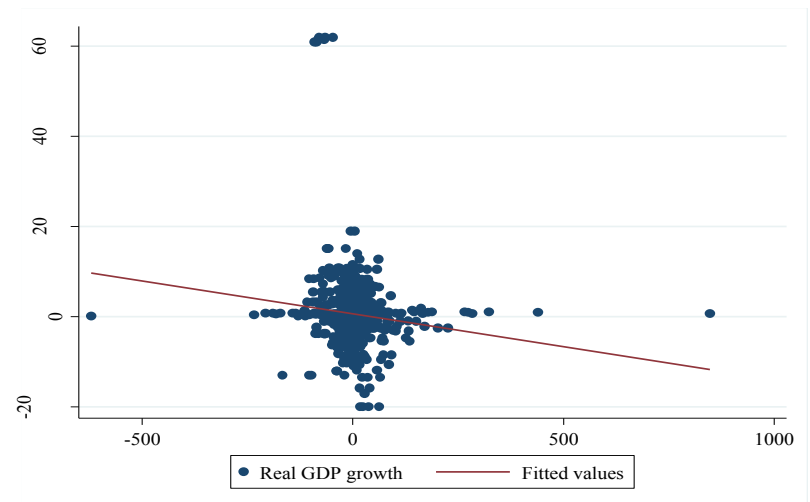

Term Spread

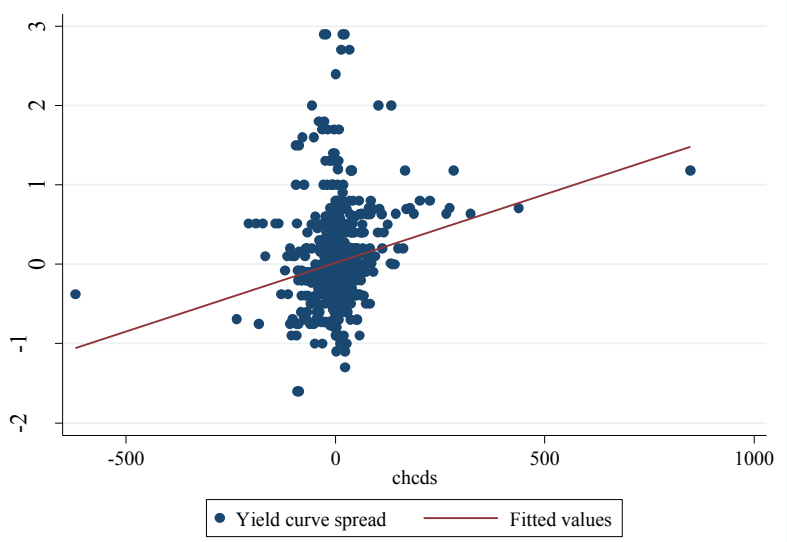




\section{ESTIMATION AND RESULTS}

\section{A. Specification 1: What determines bank funding costs across different regions?}

32. Table 1 summarizes the results, including both short-run and long-run estimates, derived from estimating Equation (3) on the core sample of banks, as well as four different sub-samples: the US, EA, UK and Nordics ${ }^{1718}$.

\section{Bank capital and fundamentals}

33. The capital variables behave as expected. In the short-run, we find that an increase in total bank capital increases bank funding costs. This positive sign on the short-run coefficient may be a reflection of adverse selection problems associated with raising capital (Myers and Majluf, 1984). By contrast, an increase in bank capital reduces funding costs in the long-runon average, a $1 \mathrm{pp}$ increase in total bank capital reduces funding costs by $0.26 \mathrm{bp}$. The impact of additional capital, in terms of reduced equilibrium funding costs, is highest for US banks, and lowest for EA banks. Similarly, we find that higher capital quality (the ratio of tier 1 capital to total capital) is also associated with lower equilibrium bank funding costs, consistent with higher capital quality signalling lower bank riskiness.

34. Not surprisingly, individual bank credit quality is strongly associated with lower funding costs. Bank provisions has the expected positive sign and is statistically significant, so that a deterioration in asset quality - an increase in balance sheet riskiness - is associated with increased bank funding costs. The results suggest US and Nordic bank funding costs are especially sensitive to changes in provisions in the short run. This could reflect the fact that forbearance practices are comparatively more predominant among European and UK banks ${ }^{19}$. Bank specific CDS liquidity, as measured by the CDS bid-ask spread is also positive and statistically significant, suggesting market illiquidity is associated with higher CDS premia. Lastly, we find not surprisingly that equity returns have a negative impact on bank funding costs, reflecting the lower probability of default of banks that are more profitable.

35. On average, funding costs rose most for US banks with the onset of the subprime crisis, and most for EA banks with the onset of the EA break-up crisis. The coefficient on the first crisis dummy — controlling for the onset of the US sub-prime crisis — is positive and statistically

\footnotetext{
${ }^{17}$ Given that the model is estimated using quarterly data, short run estimates refer to an effect lasting around $2-4$ quarters before fading away, while long run estimates refer to a more permanent effect on funding costs.

18 The results are robust to using a different proxy for funding costs (CDS-5 year + US 3 month Treasury Bill).

${ }^{19}$ See Bank of England Financial Stability Report June 2011; and ECB Financial Stability Reviews June 2012 and May 2013.
} 
significant, consistent with higher bank distress risk premia during this crisis period. As expected, the size of the coefficient is largest for US banks, consistent with US banks facing disproportionately higher funding costs during this period. The second crisis dummycontrolling for the financial crisis related to EA breakup risk-is also positive and significant, but the coefficient is largest for EA banks and smallest for US banks. UK banks' funding costs appear to have been most affected by the second (EA breakup) crisis.

36. Moreover, funding costs appear to have become more sensitive to capital since the onset of the crisis. Interacting the sub-prime crisis dummy with the capital explanatory variables generates a positive and significant coefficient, suggesting that changes in bank capital matter more for funding costs since the onset of the crisis. This may reflect investors increasingly differentiating between banks based on their level of capitalization since the onset of the crisis. And in any case, funding costs did not adequately reflect bank fundamentals, including capital ratios, before the crisis.

\section{Macro-financial variables}

37. Market indicators of bank resilience and financial market volatility are also significantly associated with bank funding costs. Both equity returns and implied market volatility only have short-run effects on funding costs. The coefficient on equity returns is negative and significant-with an increase in returns suggesting an increase in bank profitability and resilience, and lower funding costs. An increase in the implied equity market volatility - an indicator of investor risk appetite-is associated with a higher probability of default and its coefficient has the expected positive sign. An increase in EA sovereign risk-proxied by a weighted index of peripheral European country sovereign spreads-is also associated with higher funding costs.

38. On average, domestic growth considerations appear to matter more for bank funding costs than global growth prospects. Actual real GDP growth - reflecting recent or existing domestic economic conditions - has the expected negative sign, suggesting that improved growth conditions should raise bank profitability, reduce bank risk and lead to lower funding costs. Future expectations of global growth have a negative impact on bank funding costs, but this variable is only statistically significant for EA and UK banks. The latter may suggest EA and UK banks have more globally diverse operations, and are thus more reliant on global growth expectations than US and Nordic banks ${ }^{20}$.

\footnotetext{
${ }^{20}$ We have not investigated which banking systems have more globally diverse operations, but this could be an interesting subject for future extensions of our work.
} 
39. Changes in short term interest rates are positively associated with bank funding costs. We find that increases in central bank policy rates have a positive and statistically significant impact on bank funding costs. We do not directly control for non-standard central bank policy measures given the channels through which these policies should affect bank funding are captured by other variables in our model, notably the yield curve slope and financial market volatility (Carpenter, Demiralp and Eisenschmidt (2013)).

40. We find that the yield curve spread is positively related to bank funding costs, suggesting that in the short run bank funding costs rise with a steepening in the yield curve ${ }^{21}$. Changes in the yield curve slope could affect bank CDS premia via two main channels: through the direct impact on the risk free rate and secondly through the impact on the bank's credit risk $^{22}$. A steeper yield curve stemming from a rise in interest rates along the curve would be expected to translate into a direct increase in banks' funding costs ${ }^{23}$, but the size of the impact is likely to depend on the maturity structure of a bank's liabilities. The funding cost increase may be mitigated for banks whose profits rely on net income margin-given that a steeper curve means a larger spread between borrowing and lending - which would raise profits and lower a bank's riskiness. But the latter channel may work with several lags and depend crucially on the bank's ability to pass higher lending rates on to customers. The yield curve spread's positive impact on banks' funding costs could also work through a separate indirect macroeconomic channel ${ }^{24}$. Furthermore, a positive relationship (between the yield curve spread and funding costs) may result to the extent a steeper yield curve is due to investor outflows from government bonds triggered by a reduction in the credit worthiness of the sovereign. This was the case for EA countries during the sovereign debt crisis, which triggered outflows from bank debt, and an increase in bank funding costs.

\footnotetext{
${ }^{21}$ Interest rates and the yield curve slope enter the equation with several lags in order to avoid endogeneity problems associated with policy changes in response to adverse developments in financial markets or the broader macro economy, which might in turn lead to an increase in bank CDS.

${ }^{22}$ According to standard CDS pricing models, a CDS contract can be decomposed into two components. An expected loss given default component (EL), which depends on the recovery rate (R) and the probability of default (PD) and essentially captures the entity's credit risk. In addition, the market will require a risk premium (RP) for holding credit risk.

${ }^{23}$ Conversely, a flatter yield curve for example due to the effects of quantitative easing policies should lower bank funding costs along the curve, depending on the maturity structure of a bank's liabilities.

${ }^{24}$ While a steepening curve is a leading indicator of a strengthening economy, in real time it suggests economic conditions in the recent past have been weaker than usual, leading monetary authorities to lower short rates. These recent and current conditions would have had an adverse impact on a bank's credit risk.
} 


\section{Long-run bank funding costs}

41. Overall, equilibrium long-run funding costs appear to have risen for all banks in our sample over the sample period. This increase has been driven mainly by the deterioration in individual bank credit worthiness (an increase in bank riskiness as proxied by asset quality), a yield curve steepening due to increased sovereign and banking sector risk, as well as risks stemming from the global financial and EA sovereign debt crises. Increases in total bank capital and tier 1 capital during this period helped to offset some of the rise in long-run funding costs.

42. With the exception of EA periphery banks, funding costs for most banks had declined to around or below their long run equilibrium values by end-2012. Figure 5 presents the evolution of the long-run equilibrium of banks' funding costs (red line) and short-run dynamics (blue line). In 2012, Q4 actual funding costs remained above the long-run equilibrium for some of the banks in the sample, suggesting that the increase in EA stress and higher volatility had pushed funding costs above their long-run values. As these temporary shocks wear off, funding costs should converge to their long-run values. Long run funding costs had fallen to the lowest level for US and Nordic banks, mainly due to increased bank resilience-i.e, increased capitalization and a reduction in asset riskiness - but they remained elevated for EA periphery banks.

43. In particular, funding costs remained above the long-run equilibrium for roughly one half of all EA banks, i.e., mainly Italian and Spanish banks, while German and French banks' funding costs had fallen to below the long-run equilibrium. Funding costs for two out of the five US banks in the core sample remained above their long-run equilibrium price. In the case of UK banks, they had declined to below the long-run equilibrium value, with much of the decline occurring in the last few quarters of 2012. Among the Nordic banks, funding costs remained in excess of the long-run equilibrium level for only one bank out of five in our sample, at end2012.

44. Turning to the decomposition of long-run funding costs (Annex 1 Figure 1) changes in the long-run level of funding costs are mainly due to balance-sheet variables and EA sovereign risk. Pre-crisis funding costs had gradually fallen to extremely low levels-especially for US and UK banks, although EA and Nordic banks also experienced a gradual reduction. In the US and the UK, pre-crisis falling funding costs were driven by low provisions and increased bank capitalization. EA and Nordic banks' low level of funding costs pre-crisis also reflected low provisions and relatively low interest rates compared to the US and the UK.

45. The factors underlying the sharp increase in the long-run level of bank funding costs from mid-2007 vary across banks. In the US, the sharp rise was mainly driven by a deterioration in banks' asset quality, however at the same time higher capital buffers reflecting government capital injections in 2008 and improved capital quality both helped bear down on funding costs. 
This was also the case for UK banks, with the exception that the capital injections were relatively smaller than for US banks. Compared to the US and the UK, long-run bank funding costs only rose moderately for EA and Nordic banks after the onset of the 2007 subprime crisis.

46. The escalation of the EA sovereign debt crisis in early 2011 triggered the sharpest rise in EA periphery banks' long-run funding costs. The decomposition of long-run funding costs in Annex I Figure 1 shows a sharp rise in periphery banks' funding costs from early-2011. During this period, EA periphery banks' perceived riskiness rose sharply alongside their own sovereigns' credit risk. Despite the reduction in policy rates, the term spread on government debt rose sharply (with both short term and long term rates rising in tandem) as investor outflows accelerated. These outflows - including from bank debt - in turn fed through in terms of higher bank funding costs. At the same time, bank asset quality among EA periphery banks deteriorated sharply as a result of the worsening domestic economic conditions and banks' capital levels remained insufficiently low to absorb these shocks ${ }^{25}$. The impact on core EA banks' funding costs was somewhat less severe, but still sizable - they remained relatively better capitalized (especially holding high quality capital) and provisions remained low.

47. Overall, increased bank resilience was important in bringing down long-run bank funding costs. Besides the generalized reduction in EA sovereign risks, the decline in bank funding costs has to a large extent been driven by increased bank capitalization and a reduction in bank provisions. By end-2012, long-run funding costs were lowest for US banks due to the improvement in asset quality and large increase in bank capital levels. They remained highest for EA periphery banks due to their relatively low capital levels and rising provisions.

\footnotetext{
${ }^{25}$ Large scale bank recapitalization of the type undertaken by US and UK authorities in 2008 was more difficult in the EA because of the sovereign debt crisis.
} 


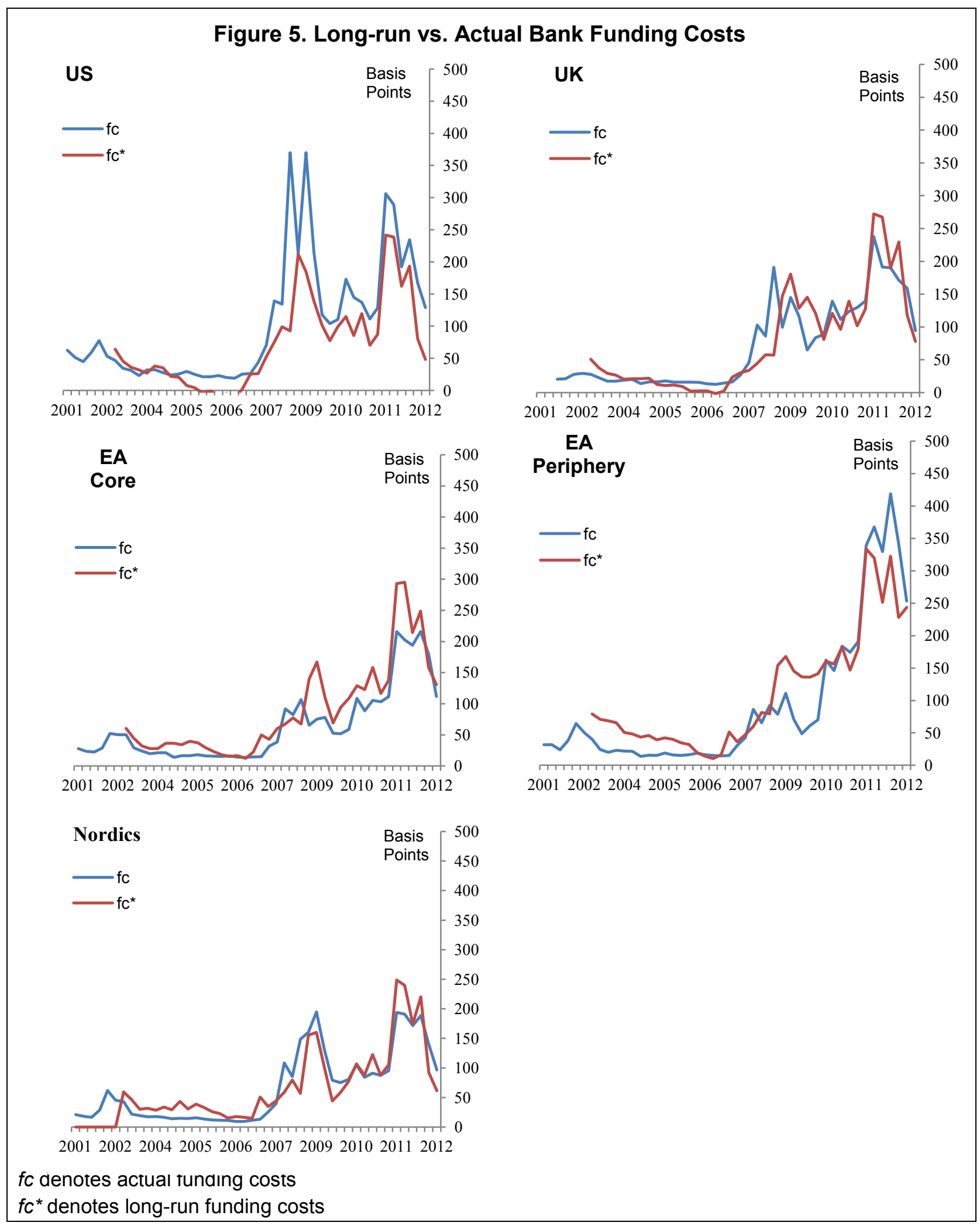




\section{B. Specification 2: Are Funding Costs Different for Domestic Systemically Important Banks (D-SIBs)?}

48. Next, we explore the extent to which funding costs for the largest banks in our sample have evolved differently compared to their peers over our sample period, given they are likely to be systemically important. In order to test this, we increase the sample of banks to include all banks which have a publically listed CDS time series within the jurisdictions we are already covering. The additional set of banks is listed in Annex 1 Table 2. We include a dummy variable set to 1 if the book assets of the bank exceed US\$500 billion in that particular quarter, indicating that the bank is systemically important (SIB $)^{26}$. We opt for this simple categorization rule, rather than for instance using the Financial Stability Board designation. First, it allows for institutions to move in and out of the SIB category if total assets fall below the US\$500 billion threshold. Also, this allows us to control for the fact that some institutions currently classified as G-SIBs by the FSB as of November 2012, were not always G-SIBs, particularly in the earlier part of our sample period.

49. We re-estimate equation (3) including a dummy for SIBs, as well as an interaction term between the $S I B$ and crisis dummies. The coefficient on these terms tells us whether bank funding costs for SIBs have differed from their peers since the onset of the two crisis periods. Table 2 summarizes the results for the full set of global banks, as well as for the main regions.

50. We find evidence that bank funding costs for SIBs were in fact lower relative to their peers over the sample period. Furthermore, this funding advantage increased with the onset of the crisis. Over the full sample period, the coefficient on the SIB dummy suggests the cost of marginal unsecured funding was on average 16 bps lower for SIBs relative to non-SIBs, and remained broadly the same after the onset of the 2007 sub-prime crisis. However, after 2011 it rose by more than 40 percent (particularly for EA SIBs), with the margin between the marginal cost of funding for SIBs and non-SIBs widening further. Post crisis, SIBs' cost of funding was roughly 22 bps lower compared to non-SIBs ${ }^{27}$. The latter likely reflects an increase in market perceptions that large banks are "too-big-to-fail" and enjoy an implicit government. Araten and Turner (2012) find that compared to non-SIBs, total funding costs for US SIBs are 9bps lower over the full credit cycle, and that in particular, unsecured funding costs for SIBs are on average 12 bps lower compared to non-SIBs ${ }^{28}$.

\footnotetext{
${ }^{26}$ This differs from a global SIB (G-SIB), whose designation criteria are set out by the Financial Stability Board. However, there is likely to be some overlap given asset size is one of the criteria used by the FSB in designating banks as G-SIBS.

${ }^{27}$ Note that the cost of funds had risen for all banks, including SIBs. The coefficient on the dummy term merely compares SIBs to non-SIBs, hence the negative term suggests a lower cost of funding for SIBs relative to non-SIBs.

${ }^{28}$ We also explore a different SIB definition-defining SIBs as the largest 2 banks in asset terms per quarter in each region. This yields slightly larger coefficients
} 
51. Turning to the results by region, the funding advantage EA SIBs appears to have risen significantly from the onset of the EA crisis, while that of US SIBs appears to be lower post2011Q2 compared to the period post-2007Q3.

Table 2. Long Run Effects on Funding Costs: SIBs and non-SIBs ${ }^{(a)(b)}$

\begin{tabular}{|c|c|c|c|c|c|}
\hline & \multirow{2}{*}{$\begin{array}{c}\text { Full Sample } \\
\text { of global } \\
\text { banks }\end{array}$} & \multicolumn{4}{|c|}{ Sub samples } \\
\hline & & $\underset{\text { banks }}{\text { US }}$ & $\begin{array}{c}\text { EA } \\
\text { banks }\end{array}$ & $\underset{\text { banks }}{\text { UK }}$ & $\begin{array}{c}\text { Nordic } \\
\text { banks }\end{array}$ \\
\hline \multicolumn{6}{|l|}{ Variables } \\
\hline SIB dummy & $\begin{array}{c}-15.81^{* * *} \\
(4.580)\end{array}$ & $\begin{array}{l}-18.24 \\
(16.10)\end{array}$ & $\begin{array}{c}-8.530 * * \\
(3.103)\end{array}$ & $\begin{array}{l}-3.875 \\
(13.49)\end{array}$ & $\begin{array}{c}-0.696 \\
(8.536)\end{array}$ \\
\hline Crisis1 dummy & $\begin{array}{c}12.54 * * * \\
(3.934)\end{array}$ & $\begin{array}{c}20.853^{*} \\
(18.08)\end{array}$ & $\begin{array}{c}4.483 * * * \\
(1.020)\end{array}$ & $\begin{array}{l}6.09^{*} \\
(3.65)\end{array}$ & $\begin{array}{l}10.90^{* *} \\
(5.061)\end{array}$ \\
\hline Crisis2 dummy & $\begin{array}{l}8.116^{* *} \\
(3.319)\end{array}$ & $\begin{array}{c}3.29 * * \\
(1.56)\end{array}$ & $\begin{array}{c}17.84 * * * \\
(6.26)\end{array}$ & $\begin{array}{c}10.131^{* * *} \\
(4.11)\end{array}$ & $\begin{array}{c}1.777 \\
(7.988)\end{array}$ \\
\hline SIB*crisis 1 & $\begin{array}{c}-15.08^{* *} \\
(6.103)\end{array}$ & $\begin{array}{c}-12.33^{* *} \\
(5.042)\end{array}$ & $\begin{array}{c}-11.14^{* * * *} \\
(3.027)\end{array}$ & & $\begin{array}{c}1.051 \\
(0.812)\end{array}$ \\
\hline SIB*crisis 2 & $\begin{array}{c}-22.30 * * * \\
(6.737)\end{array}$ & $\begin{array}{l}-9.42 * * \\
(3.990)\end{array}$ & $\begin{array}{c}-29.94 * * * \\
(10.30)\end{array}$ & & $\begin{array}{c}0.827 \\
(7.553)\end{array}$ \\
\hline
\end{tabular}

Only partial results from the full panel regressions are reported.

(a) SIB defined as banks having total book assets > US\$500billion in any given quarter.

(b) Crisis1 dummy is from 2007Q3; Crisis2 dummy is from 2011Q2

(c) Nordics includes Denmark, Sweden and Norway

Standard errors in parentheses, $* * * \mathrm{p}<0.01, * * \mathrm{p}<0.05, * \mathrm{p}<0.1$

\section{Conclusion}

52. Understanding what drives marginal bank funding costs is important because funding costs affect bank profitability, capital and ultimately the banking system's supply of credit to the real economy. Bank funding costs have risen sharply in the aftermath of the financial crisis and failed to return to pre-crisis levels even following exceptional monetary policy measures to support funding markets. We use a panel Error Correction Model to model the drivers of bank funding costs for a large set of international banks before and after the financial crisis and Euro Area sovereign crisis. This framework allows us to disentangle short run and long run effects of bank specific bank variables and macro-financial variables on marginal bank funding costs, which we assume are captured by the evolution of CDS premia.

53. We find that short run changes in bank unsecured funding costs are associated with: (i) bank-specific characteristics such as an institution's credit worthiness, and importantly, changes in the level and quality of capital; (ii) country level factors such as domestic economic growth, 
and changes in short term interest rates; and (iii) global risk factors such as implied market volatility, shocks to financial markets-notably the recent global financial crisis and EA sovereign risks - and the global growth outlook.

54. Overall, banks' long-run funding costs appear to have risen over the sample period, mainly driven by the deterioration in banks' asset quality, the decline in near term domestic growth prospects, the continued decline in short term interest rates, as well as the impact of successive financial crises - the global financial crisis and the EA sovereign debt crisis. Finally, we also find evidence that larger, systemically important banks enjoy a funding advantage, and contrary to expectations that the too-big-to-fail problem has declined following regulatory interventions we show that this advantage has risen since the onset of the crisis.

55. From a policy perspective our results suggest that regulatory efforts to strengthen banks' capital buffers may not necessarily raise banks' cost of capital and therefore reduce lending to the real economy. While efforts to undertake balance sheet repair may reduce bank lending in the short run, we find that a higher capital level leads to lower bank funding costs in the long run, therefore potentially supporting bank lending growth. 
ANNEX I

Figure 1. Decomposition of Long-run Bank Funding Costs

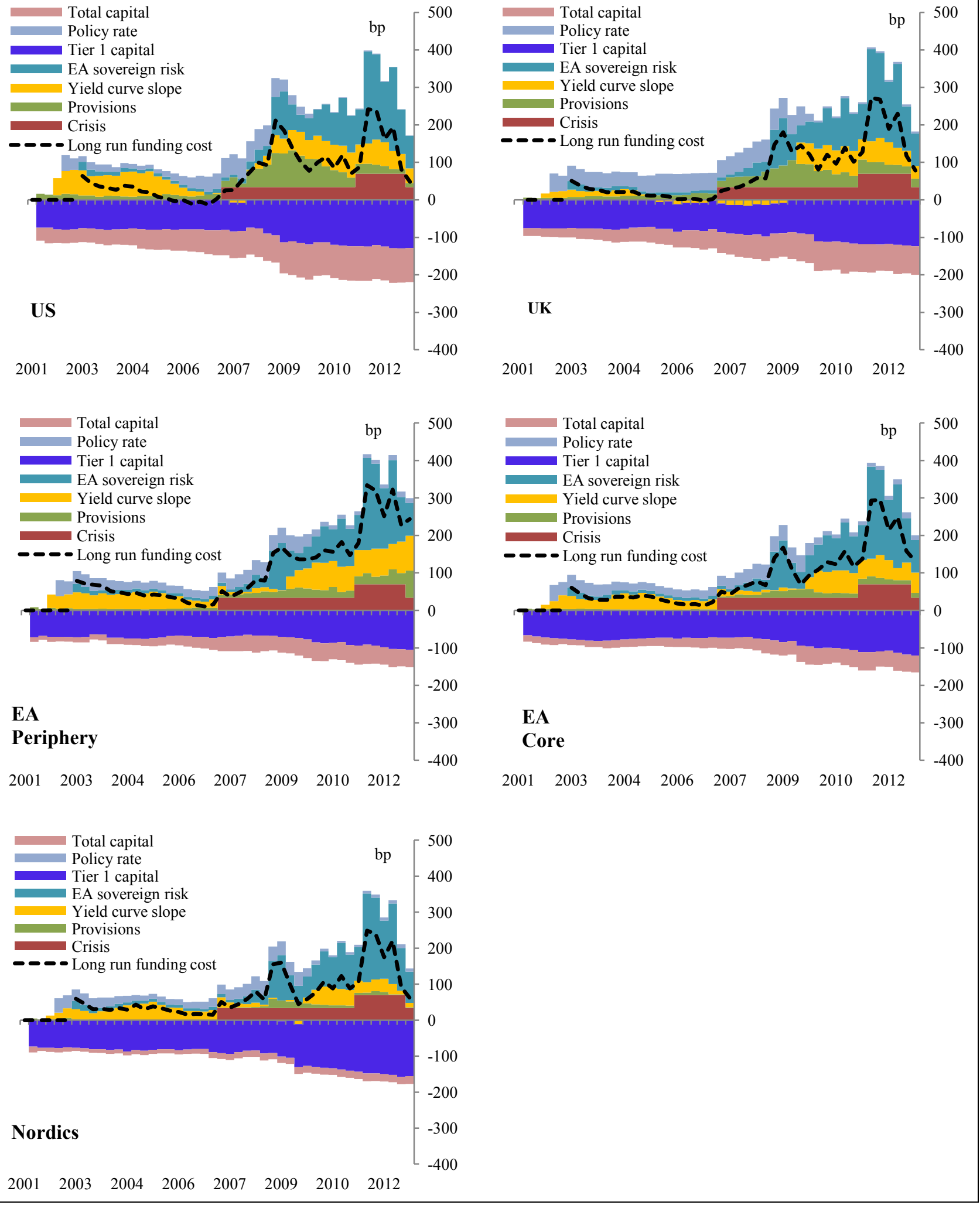

(a) The components add up to the estimated long run funding cost over the period 2001-2012 and are based on average values for factors. 
Table 1. Core Sample of Banks Used in Regressions

\begin{tabular}{|c|c|c|c|}
\hline & Bank & $\begin{array}{l}\text { Share of banking system } \\
\text { total assets, End-2012 }\end{array}$ & $\begin{array}{l}\text { Globally Systemically } \\
\text { Important Bank (G-SIB) }\end{array}$ \\
\hline 1. & $\begin{array}{l}\text { Denmark } \\
\text { Danske A/S }\end{array}$ & $\begin{array}{l}\mathbf{0 . 5 7} \\
0.57\end{array}$ & No \\
\hline $\begin{array}{l}2 . \\
3 . \\
4 .\end{array}$ & $\begin{array}{l}\text { France } \\
\text { BNP Paribas SA } \\
\text { Group Credit Agricole } \\
\text { Societe Generale SA }\end{array}$ & $\begin{array}{l}\mathbf{0 . 7 5} \\
0.29 \\
0.28 \\
0.19\end{array}$ & $\begin{array}{l}\text { Yes } \\
\text { Yes } \\
\text { Yes }\end{array}$ \\
\hline $\begin{array}{l}5 . \\
6 .\end{array}$ & $\begin{array}{l}\text { Germany } \\
\text { Deutsche Bank AG } \\
\text { Commerzbank AG }\end{array}$ & $\begin{array}{l}\mathbf{0 . 3 4} \\
0.26 \\
0.08\end{array}$ & $\begin{array}{l}\text { Yes } \\
\text { No }\end{array}$ \\
\hline $\begin{array}{l}7 . \\
8 .\end{array}$ & $\begin{array}{l}\text { Italy } \\
\text { Intesa Sanpaolo SpA } \\
\text { Unicredit SpA }\end{array}$ & $\begin{array}{l}\mathbf{0 . 6 1} \\
0.25 \\
0.35\end{array}$ & $\begin{array}{l}\text { No } \\
\text { Yes }\end{array}$ \\
\hline $\begin{array}{l}9 . \\
10 .\end{array}$ & $\begin{array}{l}\text { Spain } \\
\text { Banco Santander SA } \\
\text { BBVA }\end{array}$ & $\begin{array}{l}\mathbf{0 . 5 1} \\
0.34 \\
0.17\end{array}$ & $\begin{array}{l}\text { Yes } \\
\text { Yes }\end{array}$ \\
\hline $\begin{array}{l}11 . \\
12 . \\
13 .\end{array}$ & $\begin{array}{l}\text { Sweden } \\
\text { Handelsbanken } \\
\text { Nordea } \\
\text { Skandinaviska Enskilda Banken AB } \\
\text { (SEB) }\end{array}$ & $\begin{array}{l}\mathbf{1 . 3 6} \\
0.31 \\
0.75 \\
0.31\end{array}$ & $\begin{array}{l}\text { No } \\
\text { Yes } \\
\text { No }\end{array}$ \\
\hline $\begin{array}{l}14 . \\
15 .\end{array}$ & $\begin{array}{l}\text { Switzerland } \\
\text { Credit Suisse } \\
\text { UBS AG }\end{array}$ & $\begin{array}{l}\mathbf{0 . 7 5} \\
0.32 \\
0.44\end{array}$ & $\begin{array}{l}\text { Yes } \\
\text { Yes }\end{array}$ \\
\hline $\begin{array}{l}16 . \\
17 . \\
18 . \\
19 .\end{array}$ & $\begin{array}{l}\text { UK } \\
\text { Barclays Plc } \\
\text { Lloyds Banking Group Plc } \\
\text { Royal Bank of Scotland Group Plc } \\
\text { HSBC Holdings Plc }\end{array}$ & $\begin{array}{l}0.84 \\
0.23 \\
0.14 \\
0.20 \\
0.25\end{array}$ & $\begin{array}{l}\text { Yes } \\
\text { No } \\
\text { Yes } \\
\text { Yes }\end{array}$ \\
\hline $\begin{array}{l}20 . \\
21 . \\
22 . \\
23 . \\
24 .\end{array}$ & $\begin{array}{l}\text { US } \\
\text { Bank of America Corporation } \\
\text { Citigroup } \\
\text { Goldman Sachs Group, Inc } \\
\text { JP Morgan Chase \& Co. } \\
\text { Morgan Stanley } \\
\text { Wells Fargo \& Co. }\end{array}$ & $\begin{array}{l}\mathbf{0 . 8 9} \\
0.21 \\
0.17 \\
0.09 \\
0.22 \\
0.07 \\
0.13\end{array}$ & $\begin{array}{l}\text { Yes } \\
\text { Yes } \\
\text { Yes } \\
\text { Yes } \\
\text { Yes } \\
\text { Yes }\end{array}$ \\
\hline
\end{tabular}

(a) Financial Stability Board criteria (November 2012);

http://www.financialstabilityboard.org/publications/r_121031ac.pdf 
Table 2. Additional Set of Banks Included in Estimation

\begin{tabular}{|c|c|c|c|}
\hline & Bank & $\begin{array}{c}\text { Share of banking } \\
\text { system total assets, } \\
\text { End-2012 }\end{array}$ & $\begin{array}{l}\text { Globally Systemically } \\
\text { Important Bank (G-SIB) }^{(a)}\end{array}$ \\
\hline $\begin{array}{l}1 . \\
2 .\end{array}$ & $\begin{array}{l}\text { Austria } \\
\text { Erste Group Bank } \\
\text { Raiffeisen Zentralbank }\end{array}$ & $\begin{array}{l}\mathbf{0 . 4 0} \\
0.24 \\
0.16\end{array}$ & $\begin{array}{l}\text { No } \\
\text { No }\end{array}$ \\
\hline $\begin{array}{l}3 . \\
4 . \\
5 . \\
6 . \\
7 .\end{array}$ & $\begin{array}{l}\text { Australia } \\
\text { Macquarie Bank } \\
\text { National Australia Bank } \\
\text { Westpac } \\
\text { Australia \& New Zealand Banking } \\
\text { Group } \\
\text { Commonwealth Bank of Australia }\end{array}$ & $\begin{array}{l}\mathbf{0 . 9 7} \\
0.04 \\
0.25 \\
0.22 \\
0.21 \\
0.24\end{array}$ & $\begin{array}{l}\text { No } \\
\text { No } \\
\text { No } \\
\text { No } \\
\text { No }\end{array}$ \\
\hline $\begin{array}{l}8 . \\
9 .\end{array}$ & $\begin{array}{l}\text { Belgium } \\
\text { KBC Bank } \\
\text { Dexia }\end{array}$ & $\begin{array}{l}\mathbf{1 . 1 1} \\
0.46 \\
0.65\end{array}$ & $\begin{array}{l}\text { No } \\
\text { No }\end{array}$ \\
\hline 10. & $\begin{array}{l}\text { France } \\
\text { Natixis }\end{array}$ & $\begin{array}{l}\mathbf{0 . 0 8} \\
0.08\end{array}$ & Yes \\
\hline $\begin{array}{l}11 . \\
12 .\end{array}$ & $\begin{array}{l}\text { Germany } \\
\text { Deutsche Postbank } \\
\text { HSH Nordbank }\end{array}$ & $\begin{array}{l}\mathbf{0 . 0 4} \\
0.02 \\
0.02\end{array}$ & $\begin{array}{l}\text { Yes } \\
\text { No }\end{array}$ \\
\hline $\begin{array}{l}13 . \\
14 . \\
15 . \\
16 . \\
17 .\end{array}$ & $\begin{array}{l}\text { Italy } \\
\text { Banca Monte dei Paschi Siena } \\
\text { Banca Popolare SC } \\
\text { Banca Popolare Milano } \\
\text { Mediobanca SpA } \\
\text { Banca Nazionale del Lavoro }\end{array}$ & $\begin{array}{l}\mathbf{0 . 2 2} \\
0.08 \\
0.05 \\
0.02 \\
0.03 \\
0.03\end{array}$ & $\begin{array}{l}\text { No } \\
\text { No } \\
\text { No } \\
\text { No } \\
\text { No }\end{array}$ \\
\hline $\begin{array}{l}18 . \\
19 . \\
20 .\end{array}$ & $\begin{array}{l}\text { Netherlands } \\
\text { ING Bank NV } \\
\text { Rabobank } \\
\text { ABN Amro }\end{array}$ & $\begin{array}{l}\mathbf{0 . 9 1} \\
0.46 \\
0.30 \\
0.16\end{array}$ & $\begin{array}{l}\text { Yes } \\
\text { No } \\
\text { No }\end{array}$ \\
\hline 21. & $\begin{array}{l}\text { Norway } \\
\text { DNB Nor ASA }\end{array}$ & $\begin{array}{l}3.08 \\
3.08\end{array}$ & No \\
\hline $\begin{array}{l}22 . \\
23 . \\
24 . \\
25 .\end{array}$ & $\begin{array}{l}\text { Spain } \\
\text { Banco Popular Espanol } \\
\text { Banco de Sabadell } \\
\text { Bankinter } \\
\text { Banco Pastor }\end{array}$ & $\begin{array}{l}\mathbf{0 . 1 1} \\
0.04 \\
0.04 \\
0.02 \\
0.01\end{array}$ & $\begin{array}{l}\text { No } \\
\text { No } \\
\text { No } \\
\text { No }\end{array}$ \\
\hline $\begin{array}{l}26 . \\
27 .\end{array}$ & $\begin{array}{l}\text { US } \\
\text { Ally Financial } \\
\text { American Express }\end{array}$ & $\begin{array}{l}\mathbf{0 . 0 3} \\
0.02 \\
0.01\end{array}$ & $\begin{array}{l}\text { No } \\
\text { No }\end{array}$ \\
\hline
\end{tabular}


Table 3. CDS Premia for Sample of Banks (Basis Points)

\begin{tabular}{|c|c|c|c|c|c|}
\hline Bank & Mean & Median & Standard Deviation & Min & Max \\
\hline \multicolumn{6}{|l|}{ Core Sample: } \\
\hline Bank of America Corporation & 98.4 & 43.0 & 108.3 & 9 & 422 \\
\hline Barclays Plc & 79.5 & 38.0 & 77.6 & 6 & 257 \\
\hline BBVA & 104.0 & 31.0 & 125.2 & 8 & 445 \\
\hline BNP Paribas SA & 63.5 & 24.5 & 72.1 & 6 & 258 \\
\hline Group Credit Agricole & 79.1 & 24.0 & 85.4 & 6 & 306 \\
\hline Citigroup & 119.7 & 69.0 & 131.2 & 8 & 632 \\
\hline Commerzbank AG & 85.4 & 59.0 & 76.4 & 9 & 285 \\
\hline Credit Suisse & 72.6 & 65.0 & 57.0 & 10 & 185 \\
\hline Deutsche Bank AG & 66.2 & 41.0 & 57.2 & 11 & 193 \\
\hline Danske A/S & 81.2 & 53.0 & 90.0 & 5 & 307 \\
\hline Goldman Sachs Group, Inc & 109.0 & 65.5 & 99.9 & 20 & 419 \\
\hline Handelsbanken & 74.6 & 62.0 & 41.4 & 14 & 160 \\
\hline HSBC Holdings Plc & 54.4 & 34.5 & 47.6 & 5 & 153 \\
\hline Intesa Sanpaolo SpA & 103.8 & 46.0 & 134.2 & 7 & 482 \\
\hline JP Morgan Chase \& Co. & 67.6 & 58.5 & 45.8 & 15 & 201 \\
\hline Lloyds Banking Group Plc & 95.6 & 24.0 & 104.1 & 4 & 350 \\
\hline Morgan Stanley & 148.5 & 66.5 & 183.3 & 21 & 1033 \\
\hline Nordea & 87.7 & 81.0 & 47.8 & 12 & 171 \\
\hline Royal Bank of Scotland Group Plc & 101.9 & 24.5 & 108.9 & 4 & 369 \\
\hline Banco Santander SA & 102.3 & 45.5 & 116.4 & 8 & 425 \\
\hline Skandinaviska Enskilda Banken AB (SEB) & 77.2 & 81.5 & 70.7 & 8 & 235 \\
\hline Societe Generale SA & 79.6 & 25.5 & 93.1 & 6 & 340 \\
\hline UBS AG & 71.0 & 22.0 & 75.2 & 5 & 281 \\
\hline Unicredit SpA & 108.1 & 38.0 & 140.7 & 10 & 538 \\
\hline Wells Fargo \& Co. & 68.1 & 60.0 & 60.3 & 6 & 298 \\
\hline Total & 88.5 & 52.5 & 99.5 & 4 & 1033 \\
\hline \multicolumn{6}{|l|}{ Additional Banks: } \\
\hline ABN Amro & 83.6 & 29.0 & 91.5 & 5.8 & 331.2 \\
\hline Ally Financial & 531.7 & 333.1 & 589.8 & 100 & 2910.7 \\
\hline American Express & 91.9 & 75.0 & 113.4 & 10.6 & 631.1 \\
\hline Australia \& New Zealand Banking Group & 68.5 & 53.1 & 62.3 & 5.1 & 220.3 \\
\hline Banca Monte dei Paschi Siena & 133.2 & 43.4 & 185.8 & 7.1 & 679.1 \\
\hline Banca Nazionale del Lavoro & 79.2 & 55.7 & 76.8 & 6.6 & 282.1 \\
\hline Banca Popolare SC & 222.3 & 137.4 & 223.2 & 12.4 & 807.7 \\
\hline Natixis & 119.8 & 128.5 & 107.6 & 8.5 & 335 \\
\hline Banco Popular Espanol & 214.0 & 144.2 & 234.7 & 9.5 & 773.1 \\
\hline Banca Popolare Milano & 156.5 & 68.6 & 206.6 & 12 & 688.6 \\
\hline Bank of Tokyo-Mitsubishi UFJ & 66.6 & 65.2 & 49.7 & 6.6 & 176.2 \\
\hline Commonwealth Bank of Australia & 68.3 & 56.7 & 61.9 & 5.1 & 220.3 \\
\hline Dexia & 433.8 & 331.6 & 240.9 & 179.4 & 891.7 \\
\hline DNB Nor ASA & 59.2 & 57.6 & 51.9 & 9.5 & 172.1 \\
\hline Deutsche Postbank & 49.6 & 50.7 & 28.0 & 14.9 & 114.8 \\
\hline Erste Group Bank & 113.0 & 117.8 & 109.3 & 10.8 & 401.7 \\
\hline HSH Nordbank & 494.5 & 373.4 & 339.1 & 134.2 & 1348.7 \\
\hline ING Bank NV & 70.2 & 36.4 & 70.0 & 4.7 & 227.6 \\
\hline KBC Bank & 130.2 & 110.0 & 124.2 & 7.5 & 470.2 \\
\hline Macquarie Bank & 149.7 & 115.2 & 168.8 & 12.5 & 682.3 \\
\hline Mediobanca SpA & 103.7 & 48.5 & 126.0 & 7.5 & 501.9 \\
\hline Metlife & 153.6 & 85.7 & 175.7 & 11.9 & 840.6 \\
\hline Mizuho Financial Group & 76.7 & 75.4 & 56.9 & 7 & 216.7 \\
\hline National Australia Bank & 68.8 & 53.1 & 62.3 & 5 & 220.3 \\
\hline Nomura Holdings & 155.9 & 143.8 & 140.9 & 9.7 & 468.3 \\
\hline Rabobank & 50.6 & 19.8 & 50.6 & 3.4 & 182.7 \\
\hline Raiffeisen Zentralbank & 209.2 & 200.2 & 76.6 & 103.9 & 446 \\
\hline Banco de Sabadell & 236.6 & 162.9 & 243.8 & 11.3 & 824.9 \\
\hline Sumitomo Mitsui & 64.7 & 63.5 & 48.8 & 6.8 & 190.1 \\
\hline Westpac & 67.8 & 52.0 & 61.7 & 4.8 & 220.4 \\
\hline Total & 150.8 & 109.6 & 108.5 & 3.4 & 2910.7 \\
\hline
\end{tabular}


Table 4. Empirical Studies of Bank CDS

\begin{tabular}{|c|c|c|c|}
\hline Publication & Coverage & Bank specific controls & Macro-financial controls \\
\hline $\begin{array}{l}\text { Chiaramonte and Casu. } \\
\text { (2011) }\end{array}$ & $\begin{array}{l}57 \text { European, US, } \\
\text { Australian and Japanese } \\
\text { banks } \\
\text { Quarterly observations } \\
\text { Panel } \\
3 \text { periods: 2005-2007; } \\
\text { 2007-2009; 2009-2010 }\end{array}$ & $\begin{array}{l}\text { - } \text { Asset quality: Loan Loss } \\
\text { Reserves/Gross Loan; } \\
\text { Unreserved impaired } \\
\text { loans/equity } \\
\text { - } \quad \text { Capital: Tier 1 ratio; } \\
\text { - Leverage: Equity/ Assets } \\
\text { - Operations: ROA, ROE } \\
\text { - } \quad \text { Liquidity: Net } \\
\text { loans/Deposits and ST } \\
\text { funding; Liquid } \\
\text { assets/Deposits \& Short } \\
\text { term funding }\end{array}$ & \\
\hline $\begin{array}{l}\text { Annaert, J., et al (May } \\
2010 \text { ) . National Bank } \\
\text { of Belgium. }\end{array}$ & $\begin{array}{l}31 \text { EA banks } \\
\text { Jan } 1,2004-\text { Oct } 22, \\
2008 \\
\text { Weekly observations }\end{array}$ & 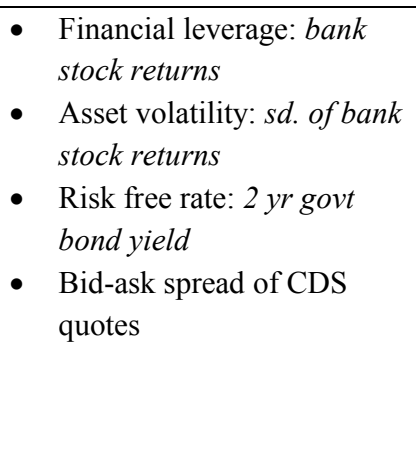 & $\begin{array}{l}\text { - } \text { Growth outlook: term } \\
\text { structure slope } \\
\text { - General business climate: } \\
\text { market stock return index } \\
\text { i.e., EA stock return } \\
\text { - } \quad \text { Investor Risk Aversion: } \\
\text { VSTOXX volatility index } \\
\text { - Market liquidity } \\
\text { strains/banking stability: } \\
\text { swap spreads and corporate } \\
\text { bond spreads }\end{array}$ \\
\hline $\begin{array}{l}\text { Volz and Wedow } \\
\text { (2009) Deutsche } \\
\text { Bundesbank }\end{array}$ & $\begin{array}{l}91 \text { banks from } 24 \\
\text { countries } \\
\text { Monthly observations }\end{array}$ & $\begin{array}{l}\text { - } \quad \text { Size: TBTF (market cap) } \\
\text { - } \quad \text { Size squared } \\
\text { - } \quad \text { Bank CDS Liquidity } \\
\text { - } \quad \text { Bank Risk: Moody's EDF } \\
\text { - } \quad \text { Liquidity: Trading days per } \\
\text { month } \\
\text { - } \text { Diversification (monthly } \\
\text { volatility of daily bank } \\
\text { equity returns) }\end{array}$ & $\begin{array}{l}\text { - } \\
\text { - } \text { Economic free rate (swap rate) } \\
\text { curve slope) }\end{array}$ \\
\hline $\begin{array}{l}\text { Raunig and Scheicher } \\
\text { (2008) }\end{array}$ & $\begin{array}{l}213 \text { European and US } \\
\text { firms } \\
\text { Monthly data } 1 / 2003- \\
12 / 2007 \\
\text { CDS premia on } 5 \mathrm{Y} \text { senior } \\
\text { debt }\end{array}$ & $\begin{array}{ll}\text { - } & \text { Moody's KMV EDF } \\
\text { - } & \text { Swap spread (bid-ask } \\
\text { spread) US\$ and Euro } 10 \\
\text { year swap spreads }\end{array}$ & $\begin{array}{l}\text { - } \text { Risk free } 5 \text { yr rate } \\
\text { - } \quad \text { Yield curve slope ( } \\
\text { - } \quad \text { Stock market volatility (VIX, } \\
\text { VSTOXX) } \\
\text { - } \quad \text { Idiosyncratic equity } \\
\text { volatility (firm stock return } \\
\text { - market wide stock return } \\
\text { as measured by S\&P 500 or } \\
\text { EuroStoxx 50) }\end{array}$ \\
\hline Yibin, B., et al. (2005) & $\begin{array}{l}\text { Jan 2001-Dec } 2003 \\
\text { Monthly obs. } \\
304 \text { firms (incl. banks) }\end{array}$ & $\begin{array}{l}\text { - Individual firm equity } \\
\text { volatility measures } \\
\text { - Firm balance sheet } \\
\text { variables e.g., leverage, } \\
\text { ROE, dividend payout }\end{array}$ & $\begin{array}{l}\text { - S\&P average daily return } \\
\text { and } S D ; S T \text { rate; yield curve } \\
\text { slope }\end{array}$ \\
\hline
\end{tabular}




\section{ANNEX II: Trends In ThE COST AND VOLUME OF BANK FUnding}

1. This annex reviews trends in the cost and volume of different types of bank funding since the onset of the 2007 global financial crisis: deposits, interbank funding and secured funding across the major banking systems.

2. Deposits: During a financial crisis investor risk appetite declines, leading to a "flight to liquidity" and a rise in cash hoarding as well as a rise in household precautionary savings (Mody et. al (2012)). Provided the sovereign's finances ensure a credible backstop, this would trigger inflows into the banking system resulting in a decline in a bank's cost of deposit funding. In general, this was the case in the US and the UK, where the average cost of deposits fell steadily from 2008, but not entirely the case in the EA (Annex II Figure 2). In fact, the average effective cost of deposits rose for some banks in the EA, with the increase most pronounced for Spanish and Italian banks while cost rises were more moderate for French and especially German banks. The increase in deposit costs in periphery EA countries reflected the accelerating deposit flight experienced by these banking systems as the EA sovereign debt crisis intensified during 20112012.

3. In contrast, the average cost of deposit liabilities for major US banks declined steadily after the start of the global financial crisis. The increased availability of deposits reflected a confluence of factors, including: (i) the build-up in corporate liquidity and cash buffers resulting from an increase in firms putting off investment decisions amidst deteriorating economic conditions; (ii) regulatory developments, in particular, the FDIC's introduction of an unlimited guarantee of deposit balances in 2008 fearing a run on bank deposits, as well as the Dodd-Frank mandated guarantee of non-interest bearing deposits from 2011-2012; and (iii) the sudden "flight to safety" out of money market funds because they were perceived to be riskier than bank deposits in the wake of the Lehman failure ${ }^{29}$. Together with the expansion in money supply in the context of the Federal Reserve's monetary policy response to the financial and economic shock, and increased household deleveraging, these regulatory interventions resulted in an increase in banks' deposit balances in the environment of heightened risk aversion.

4. The average cost of deposits for the major UK banks also declined steadily from 2008, but the evolution was bifurcated. The average effective cost of deposits fell sharply for the relatively stronger banks, and only moderately for the weaker ones ${ }^{30}$. This overall downward

\footnotetext{
${ }^{29}$ Outflows from the money market fund sector accelerated after the Lehman failure, during which period the Reserve Primary Fund "broke the buck" i.e., its net asset value fell below one US dollar, on account of its significant exposure to Lehman commercial paper. Conditions in the sector began to stabilize after government intervention, including liquidity provision and temporary insurance.

${ }^{30}$ By stronger banks, we mean those that did not require government capital injections.
} 
trajectory is likely explained by some of the same factors as in the US, in particular, the Central Bank's monetary expansion in the wake of the financial crisis, as well as household deleveraging and the increase in precautionary savings.

Figure 2. Average cost of deposits ${ }^{(a)(b)}$

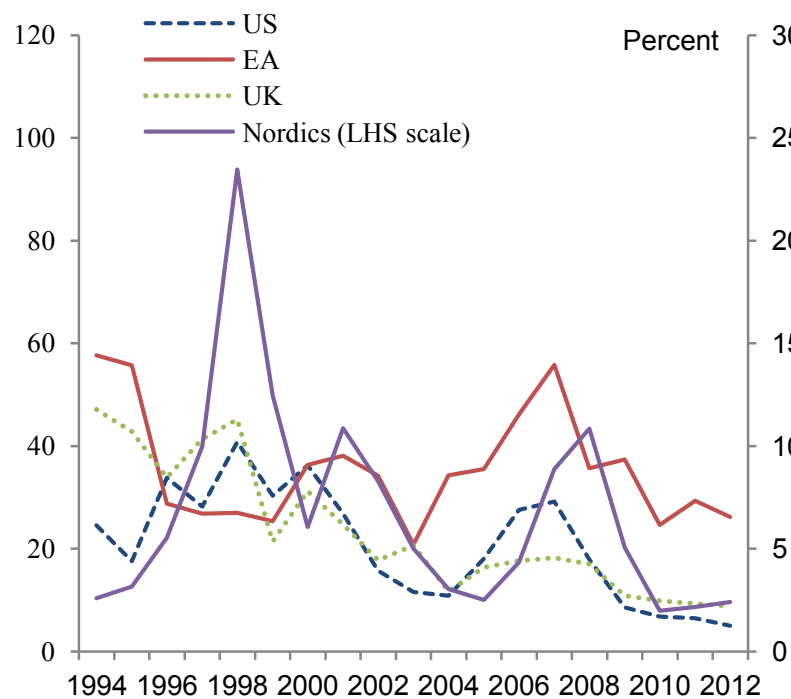

(a) Calculated as Total Interest Expense on Deposits/Total Interest bearing deposits

(b) Banks included in each category are detailed in Annex 1 Table 1. EA refers to France, Germany, Italy and Spain. Nordics refers to Denmark, Sweden and Switzerland.

Figure 4. 3month Interbank Spreads

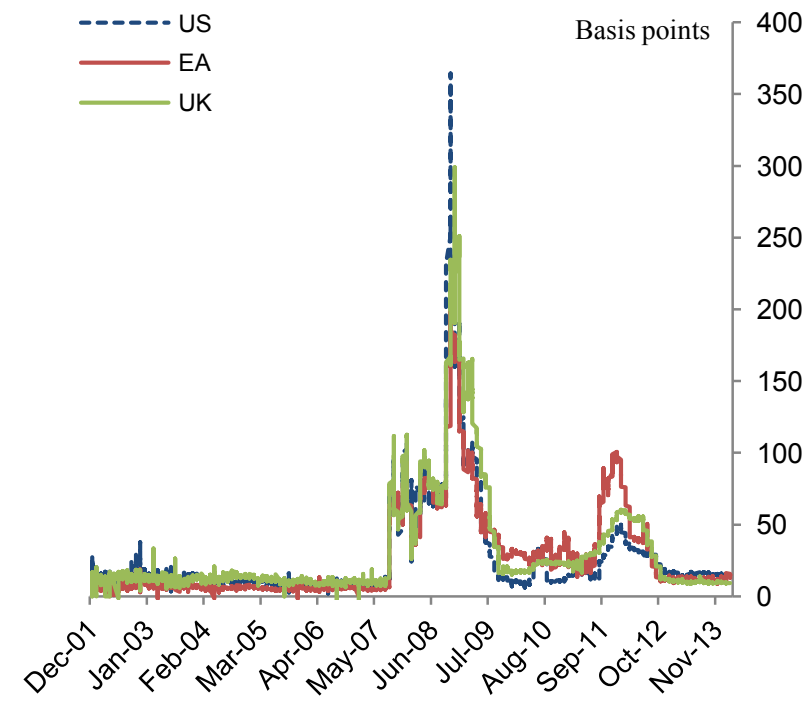

(a) US is US LIBOR-OIS spread (3month)

(b) EA is EURIBOR-OIS spread (3month)

(c) UK is LIBOR-OIS (3month)
Figure 3. Overnight Interbank Rate Spreads

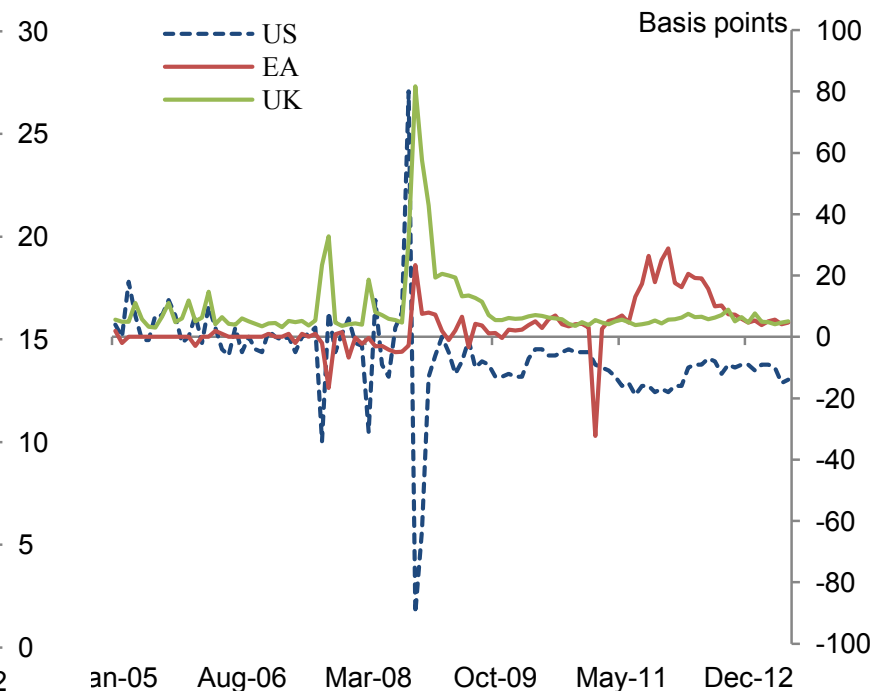

(a) US is the spread between the Fed Funds Effective and Target Rates

(b) EA is the spread between EURIBOR and EUREPO overnight

(c) UK is the LIBOR-OIS overnight spread

Figure 5. Cost of Bank Debt ${ }^{(a)}$

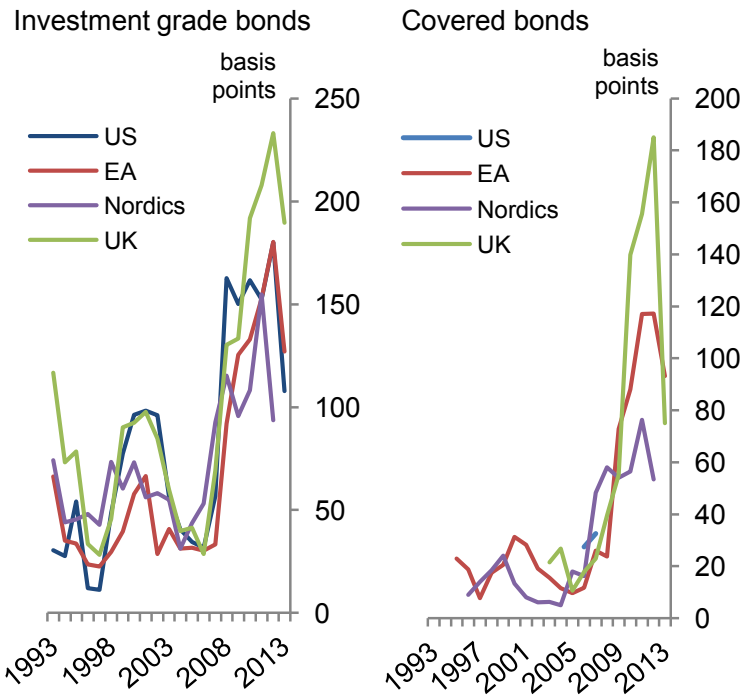

Source: Dealogic

(a) Spread to benchmark rate (10 year US Treasury) 
5. Interbank funding: Major disruptions in the interbank funding market in August 2007 are often highlighted as the first sign of the global financial crisis. Annex II Figures 3-4 illustrate the sharp rise in interbank funding across different regions during this period. However, these interbank spreads do not necessarily imply accessibility to interbank funding at these costs, not least because many banks were effectively frozen out of the interbank market altogether on fears of counterparty risk. Acharya and Merrouche (2010) find evidence of interest rate contagion through the UK interbank market during this period-the funding risk of banks rose, which led to weaker banks in particular hoarding liquidity, in turn giving rise to an increase in interbank rates in both secured and unsecured markets. In the US, the overnight federal funds effective rate (the rate at which banks borrow from each other on an overnight basis) rose sharply at the start of the financial crisis but came down quickly following significant intervention by the Federal Reserve. However, rates on longer term interbank loans, measured by the 3month London Interbank Offered Rate (LIBOR) surged and remained elevated and disconnected from the target federal funds rate for a period of time, despite the Federal Reserve's intervention (Taylor and Williams, 2009). In the EA, the cost of interbank market funding rose owing to increased uncertainty around counterparty creditworthiness (Angelini, Nobili and Picillo (2011), and ECB (2012) and banks became increasingly dependent on ECB liquidity operations and overnight borrowing post-Lehman collapse.

6. Secured debt: The cost of bank debt (both secured and unsecured) increased substantially from 2007 across all types of securities, including covered bonds (Annex II Figure 5). The sharp increases occurred simultaneously across banking systems and coincided with periods of intensified market stress. However, there was also some divergence within individual banking systems, as spreads on unsecured funding rose faster for some banks than others.

7. Since mid-2007, the quantity of wholesale funding issued by international banks has fallen sharply and remains low by historical standards. Both secured and unsecured funding fell equally, reaching levels not seen since the early 2000s (Figures 6-7). In particular, the crises interrupted access to collateralized debt markets - global issuance of asset and mortgage backed securities collapsed and remained low at end-2013, while new issuance in the covered bond markets also remained well below historical levels.

8. There are some key differences across regions and within individual banking systems, in how the pattern of secured debt funding has evolved (Figure 8). US banks initially led the increase during the mid-1990s, with their issuance dominated by asset-backed and in particular mortgage backed instruments. At the peak of issuance in early 2007, roughly two thirds of all term debt issued by US banks was in mortgage backed securities. Like US banks, UK bank issuance was also skewed toward secured funding, and in particular mortgage backed securities and covered bond instruments. European banks on the other hand, appeared increasingly equally reliant on both secured and unsecured funding sources. 
9. With the start of the crisis in mid-2007, new issuance collapsed simultaneously across all major financial centres - the Euro Area, the US and the UK, and with respect to both secured and unsecured funding sources. The decline in new issuance was especially precipitous for US banks, with both secured and unsecured issuance essentially slowing to a halt during 2008, on the back of the downward correction of the US housing market. There has been some recovery since then, particularly with respect to unsecured debt, but US banks' issuance of collateralized debt securities remains negligible. Unlike the US, new debt issuance by EA banks' was mainly in the form of asset backed securities and covered bonds. New issuance of both secured and unsecured debt by EA and UK banks has continued its downward trajectory, and does not appear to have bottomed out yet.

Figure 6. Secured Debt Issuance ${ }^{(a)(b)}$

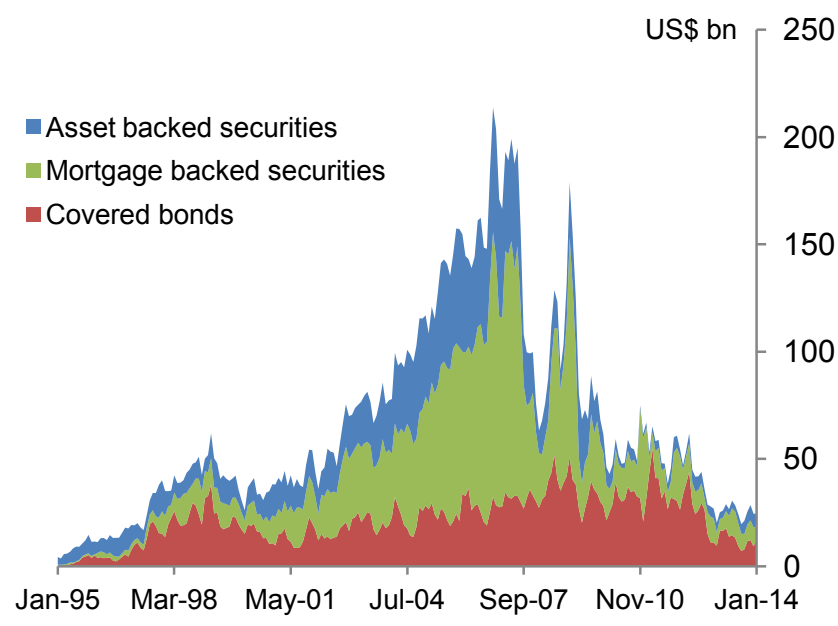

Figure 7. Unsecured Debt Issuance ${ }^{(a)(b)}$

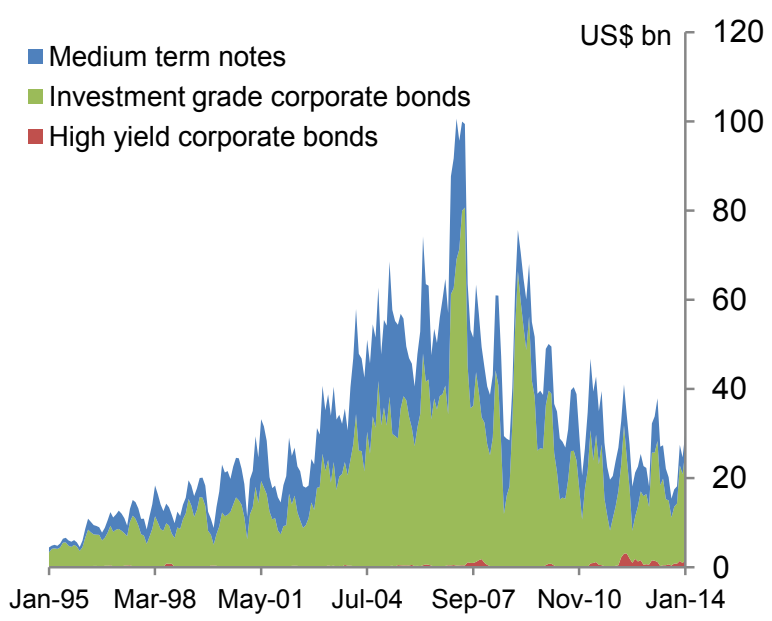

Figure 8. Debt Issuance by Region ${ }^{(a)(b)}$

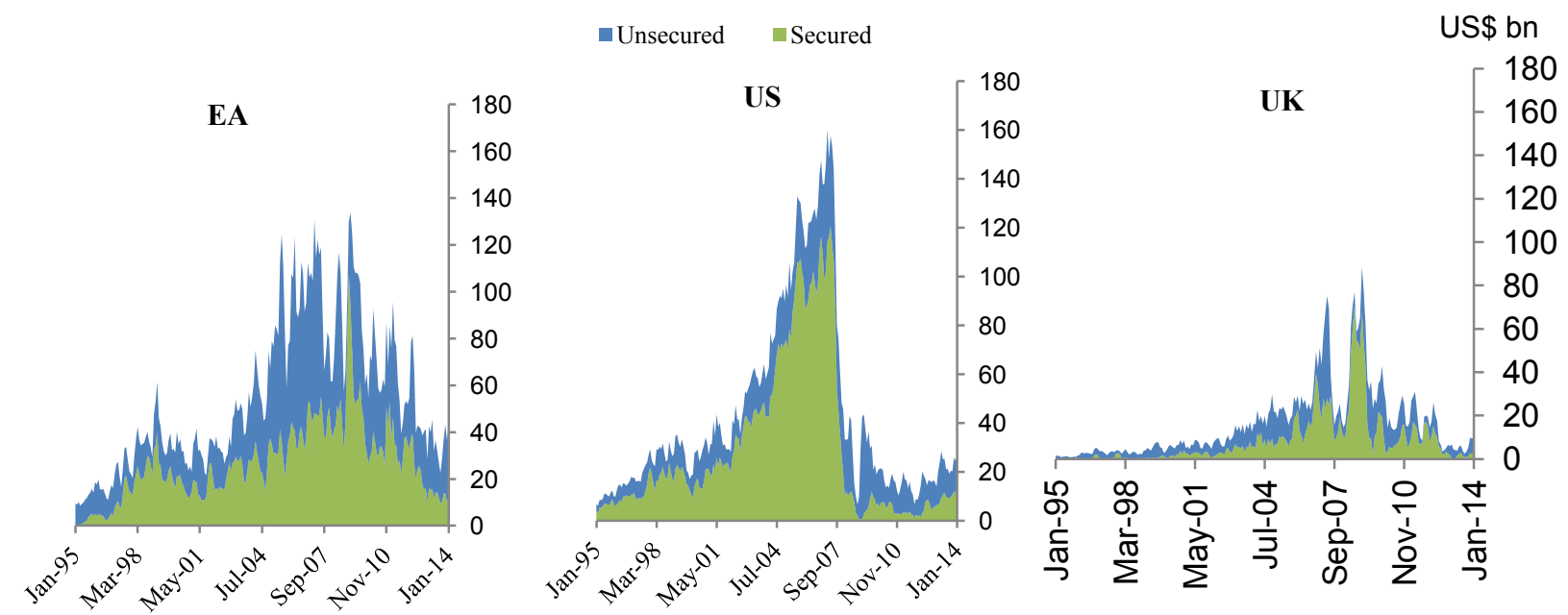

Source: Dealogic and authors' estimates

(a) Includes major international banks in the EA, the US, UK and Nordic countries.

(b) Secured debt includes mortgage and asset backed securities and covered bonds; unsecured debt includes medium term notes, high yield and investment grade bonds. 
10. In response to these trends, banks have significantly altered the size and composition of their funding (Figure 9).

- US banks in particular have sharply increased their reliance on retail deposits. From 2007 to 2012 total US banking system deposits rose by US\$27trillion, while repo funding, interbank funding and debt issuance as a proportion of total assets fell substantially. While the US banking system has traditionally been highly reliant on deposit funding, deposits as a share of total liabilities had declined steadily from a peak of close to 85 percent in 1991 to a trough of 67 percent of total liabilities in 2008, as banks increasingly relied on market sources of funding such as repos and collateralized term funding. Since 2008, the share of deposit funding for the banking system as a whole has risen sharply to 76 percent of total liabilities at end-2012. Mainly reflecting the strong inflow of deposits, total banking system liabilities have also risen steadily since 2007, peaking at US\$13 trillion at end-2012.

- EA banks responded to changes in funding conditions primarily by reducing their funding requirements and disposing of assets. From 2007-12, core EA (France and Germany) and periphery EA (Italy and Spain) total banking system assets fell by some US\$610bn and US\$645bn, respectively. EA banks also restructured their financingmarket funding in the form of collateralized term funding, derivatives and interbank funding was replaced by a combination of central bank funding and in some cases, customer deposits $^{31}$. The overall share of customer funding in total liabilities started to increase, marking a broad shift relative to the pre-crisis period when it had declined. Among core EA banks, customer funding accounted for the bulk of bank liabilities in 2012 - in 2007, the bulk of bank assets were funded through issuance of debt securities. Among periphery EA banks, the decline in debt issuance has largely been replaced by increased recourse to central bank funding.

- Like EA banks, UK banks initially contracted their balance sheets beginning in 2007. However since 2009, total banking system assets have risen again to near pre-crisis levels supported by an increase in customer deposits and central bank financing ${ }^{32}$. Reliance on wholesale funding market sources, such as interbank and term funding fell sharply

\footnotetext{
${ }^{31}$ It is difficult to isolate the impact of ECB long term refinancing operations (LTRO) funding on bank's balance sheets. Some banks report it in "deposits from banks", while other banks report it in "other liabilities".

${ }^{32}$ In 2012, the Bank of England launched the Funding for Lending Scheme. It allows banks to borrow cheaply at the Bank's Discount Facility provided these funds are put towards increased lending growth.
} 
- Contrary to the experience of all the other banking systems, the Nordic banks maintained a strong reliance on collateralized term funding, notably covered bonds. The robustness of the Nordic covered bond market reflected a combination of factors, including: (i) greater availability of collateral, in turn supported by the robustness of Nordic housing markets; (ii) the stability of the Nordic covered bond market, in particular the strength of the underlying credit quality; and (iii) the relatively stronger performance of Nordic banks during the crisis, compared to the rest of the European banking system and the region's "safe haven" status during the EA crisis. Like the US, total banking system assets have risen, driven by an increase in term debt issuance, derivatives funding and to a lesser extent customer deposits. Nordic banks' reliance on interbank funding has fallen sharply since the beginning of the crisis.

Figure 9. Structure of liabilities for major banking systems

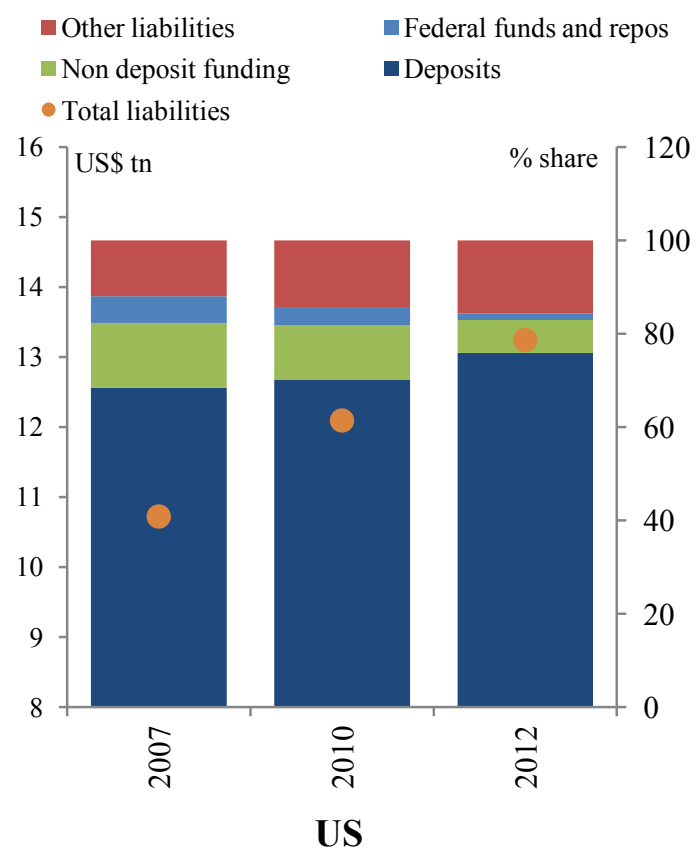

Source: US Flow of Funds Notes:

(a) Other liabilities includes taxes payable and unidentified miscellaneous liabilities

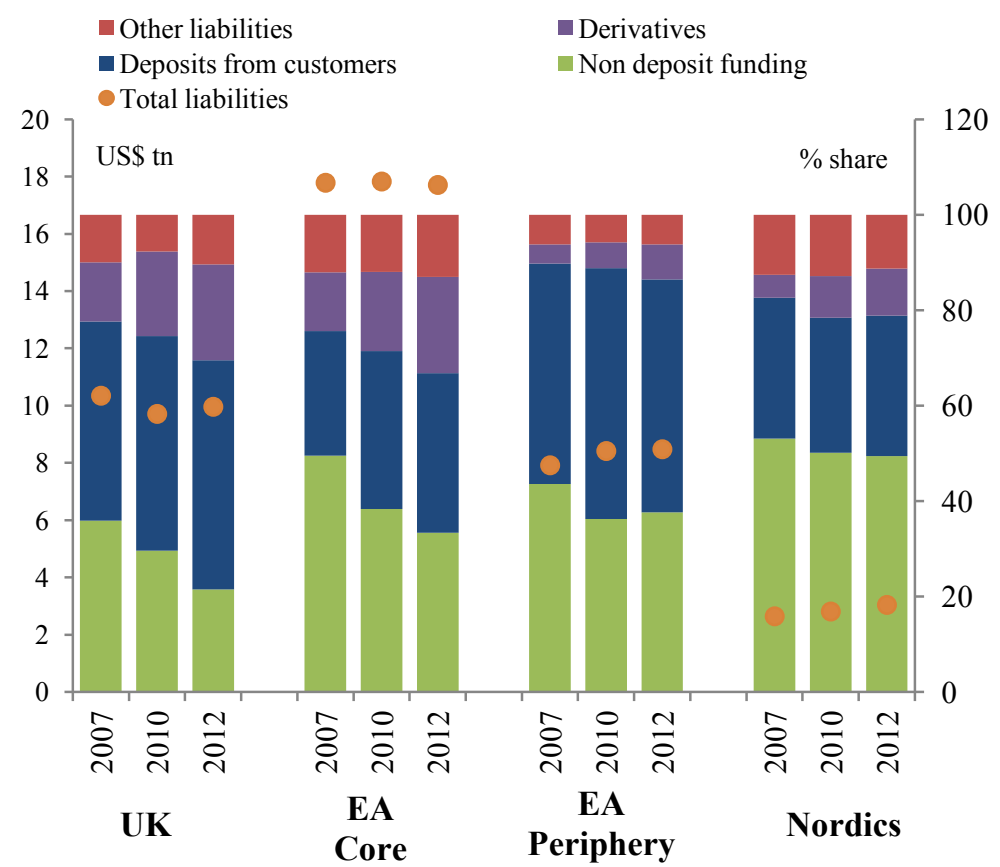

Source: SNL Financial Notes:

(a) Other liabilities" includes Tier 2 capital, short positions, insurance liabilities and derivative contracts with negative marked-to-market value. 


\section{References}

Acharya, Viral, V. and Ouarda Merrouche, (2010). "Precautionary Hoarding of Liquidity and Interbank Markets: Evidence from the Sub-prime Crisis,” NBER Working Paper 16395.

Admati, A, DeMarzo, P, Hellwig M, and Pfleiderer P. (2010) "Fallacies, Irrelevant Facts, and Myths in Capital Regulation: Why Bank Equity is Not Expensive". Stanford University Working Paper No. 86.

Angelini, P, Andrea Nobili, and Maria Cristina Picillo. (2011). "The Interbank Market After August 2007: What has changed and Why?'Journal of Money, Credit and Banking, Vol.43(5), 923-958.

Araten, Michel and Christopher Turner (2012), "Understanding the Funding Cost Differences between Global Systemically Important Banks (G-SIBs) and Non-G-SIBs in the United States," JPMorgan Chase.

Ballester Miquel, Laura, Barbara Casu Lukac, Ana González-Urteaga (2013), "Bank CDS Spreads and Banking Fragility," Electronic copy at:

http://www.efmaefm.org/0EFMAMEETINGS/EFMA\%20ANNUAL\%20MEETINGS/2013Reading/papers/EFMA2013_0018_fullpaper.pdf

Beltratti, Andrea and Rene Stultz (2012) "The credit crisis around the globe: Why did some banks perform better?" Journal of Financial Economics, 2012, v105(1), 1-17.

Button, Richard, S Pezzini and N Rossiter (2010) "Understanding the price of new lending to households", Bank of England Quarterly Bulletin, 50:4.

Carpenter, Seth B., S Demiralp and J. Eisenschmidt, 2013. "The effectiveness of the nonstandard policy measures during the financial crises: the experiences of the Federal Reserve and the European Central Bank,"Finance and Economics Discussion Series 2013-34, Board of Governors of the Federal Reserve System (U.S.).

Cornett, Marcia, Jamie McNutt, Philip Strahan, and Hassan Tehranian. (2011). "Liquidity Risk Management and Credit Supply in the Financial Crisis. ” Journal of Financial Economics 101(2), pp. 297-312.

Dagher, Jihad and Kazimov, Kazim, Banks' Liability Structure and Mortgage Lending During the Financial Crisis (October 1, 2012). IMF Working Paper, No 12/155.

Dean Baker \& Travis McArthur, (2009). "The Value of the "Too Big to Fail” Big Bank Subsidy," CEPR Reports and Issue Briefs 2009-36, Center for Economic and Policy Research (CEPR 
Demirgüç-Kunt, Asli and Huizinga, Harry, Are Banks Too Big to Fail or Too Big to Save? International Evidence from Equity Prices and CDS Spreads (January 2, 2010). CentER Discussion Paper Series No. 2010-59.

Demirgüç-Kunt, Asli \& Huizinga, Harry, 2010. "Bank activity and funding strategies: The impact on risk and returns," Journal of Financial Economics, Elsevier, vol. 98(3), pages 626650, December.

Eichengreen, Barry, Ashoka Mody, Milan Nedeljkovic, and Lucio Sarno (2009), "How the Subprime Crisis Went Global: Evidence From Bank Credit Default Swaps," NBER Working Paper 14904, April.

Financial Stability Report, 2011(2), Bank of England.

FithRatings Global Special Report (June 2011). "Trends in Bank Funding Profiles".

Francis A. Longstaff, Jun Pan, Lasse H. Pedersen, and Kenneth J. Singleton, 2007. "How Sovereign is Sovereign Credit Risk," NBER Working Papers 13658, National Bureau of Economic Research.

Funding Patterns and Liquidity Management of Internationally Active Banks, Committee on the Global Financial System (CGFS) Papers, No 39, May 2010.

International Monetary Fund, 2013, "Changes in Bank Funding Patterns and Financial Stability Risks," Global Financial Stability Report, World Economic and Financial Surveys (Washington; October)

Ivashina, Victoria, and David S. Scharfstein. "Bank Lending During the Financial Crisis of 2008." Journal of Financial Economics 97, no. 3 (September 2010): 319-338.

Kashyap, Anil, Jeremy C. Stein, and Samuel G. Hanson (2010), 'An Analysis of the Impact of 'Substantially Heightened' Capital Requirements on Large Financial Institutions', Mimeo.

Le Lesle, V., (2012). “Bank Debt in Europe: Are Funding Models Broken?” IMF Working Paper WP/12/299.

Li, Zan, Shisheng Qu, and Jing Zhang (2011), "Quantifying the Value of Implicit Government Guarantees for Large Financial Institutions,” Moody’s Analytics Quantitative Research Group.

Miles, David, Jing Yang and Gilberto Marcheggiano (2012), "Optimal Bank Capital," The Economic Journal, 123 (March), 1-37. 
Mody, Ashoka, Franziska Ohnsorge and Damiano Sandri (2012). "Precautionary Savings in the Great Recession", IMF Working Paper WP/12/42.

Myers, Stewart, and Nicholas Majluf (1984). "Corporate Financing and Investment Decisions When Firms Have Information that Investors Do Not Have." Journal of Financial Economics $13,187-221$.

Pablo Federico \& Francisco F. Vazquez, 2012. "Bank Funding Structures and Risk: Evidence from the Global Financial Crisis," IMF Working Papers 12/29, International Monetary Fund.

Pozsar, Zoltan., T. Adrian, A. Ashcraft and H. Boesky (2012). "Shadow Banking”. Federal Reserve Bank of New York, Staff Report No. 458.

Raddatz, Claudio, 2010. "When the rivers run dry : liquidity and the use of wholesale funds in the transmission of the U.S. subprime crisis," Policy Research Working Paper Series 5203, The World Bank.

Ritz, Robert.A., (2012). "How do banks respond to increased funding uncertainty?" Cambridge Working Papers in Economics 1213, Faculty of Economics, Cambridge University

Stephane Priaulet (2008), "Are credit spreads paying enough? How models can help find the answer." A theoretical discussion of JP Morgan's "Rock Bottom Price" CDS pricing model.

Taylor, John B. and John C. Williams (2009). "A black swan in the money market.” American Economic Journal: Macroeconomics 1, 58.83.

Kenichi Ueda and Beatrice Weder di Mauro (2012).”Quantifying Structural Subsidy Values for. Systemically Important Financial Institutions.” WP/12/128

van Rixtel, Adrian., and Gabriele Gasperini (2013). "Financial crises and bank funding: recent experience in the euro area.” BIS Working Paper No.406.

Warburton, A. Joseph, Anginer, Deniz and Acharya, Viral V., (2013) "The End of Market Discipline? Investor Expectations of Implicit State Guarantees" Available at SSRN: http://ssrn.com/abstract=1961656 or http://dx.doi.org/10.2139/ssrn.1961656 